VÁRADI SZABÓ Zsuzsa - HIDEGH Anna Laura - BOKOR Attila - FERTETICS Mandy

\section{KARRIERVÁLTÓK MAGYARORSZÁGON - A KARRIERVÁLTÁS FOLYAMATA}

A szerzók kutatásukban olyan emberek élettörténetét kívánták feldolgozni, akiknek volt egy vagy több jelentő́s karrierváltásuk, például társadalmi szférát, szakterületet vagy munkaeró-piaci státust váltottak. A kutatás fókuszában a karrierváltások folyamatának, a döntések meghozatalának, valamint azok tágabb kontextusának megértése áll. A tanulmány elôzố részében (Vezetéstudomány, 2009. 11. szám) bemutatták a kutatás kiindulópontjait és módszertanát, valamint a karrierváltó csoportok jellemzőit, most a karrierváltás folyamatára helyezték a hangsúlyt. Azt kívánták leírni és magyarázni, hogyan és miért lettek karrierváltók alanyaik, milyen folyamatban születtek meg döntéseik. Ehhez kiindulópontként bemutatják a karrierértelmezés és a karrierrel kapcsolatos magatartás változását magyarázó legfontosabb elméleteket, amelyek keretet adnak az újszerú karrier és a karrierváltások elemzéséhez is. Kutatási eredményeiket a karrierváltási folyamat történeteinek értelmezésén keresztül összegzik: három fö́ karrierváltási narratívatípust elemeznek a váltási folyamat legoób befolyásoló elemeit bemutatva $A$ C megállapításainak és a kutatás eredményeinek összegzéséból származó konklúziókra.

Kulcsszavak: karrier, karrierváltás, kvalitatív kutatás, narratív interjú, boundaryless (határváltó) karrier, protean (formaváltó) karrier, identitás, identitásváltozás

A Karrierváltók Magyarországon kutatási projekt so- jellege, az elemzés módja a narratív és a tartalmi elemerán olyan emberek élettörténeteit vizsgáltuk, akiknek ket egyaránt ötvözi (Lieblich, 1998), melynek elméleti az életében volt egy vagy több jelentős karrierváltás. és módszertani indoklására még kitérünk. A minták beA ,jelentôs" számunkra azt jelenti, hogy például az il- mutatása alkalmat ad arra is, hogy az elméleti megfonletố váltott a társadalmi szférák között (üzletbốl a ci- tolásokat továbbgondoljuk, így a cikk végén az elméleti vil életbe, közszolgálatból vállalkozásba stb.), esetleg keret tükrében fogalmazzuk meg konklúzióinkat. teljesen más szakmai területen helyezkedett el, vagy éppen elhagyta vezetôii pozícióját és vállalkozó lett. A téma izgalmát többek között az a kíváncsiságunk A tá, hogy mérétsïk, hogyan lettek karrierváltók an-

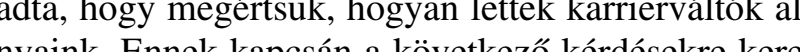

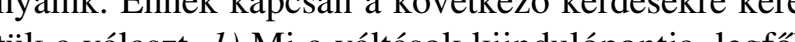
tük a választ. l) Mi a viltások kilndulópontja, legfốb mozgatórugója? 2) Milyen tényezôket mérlegelnek dontés meghozatalakor? 3) Milyen szakaszokban megy végbe a váltás? 4) Mire ad választ, megoldást a váltás? 5) Hogyan élik meg a váltási folyamatot?

Elôször áttekintést adunk a szakirodalomban található, az újszerú karrierrel kapcsolatos magatartást magyarázó legfontosabb elméletekról, majd a kutatási eredményeink alapján a karrierváltás folyamatát három minta leirááaval és elemzésével magyarázzuk. A minták

\section{Az újszerú karrierrel kapcsolatos elméletek}

Az utóbbi két évtized karrierrel kapcsolatos irodalmának központi témája a karrierrel kapcsolatos viselkedés, illetve a karier ételmezéśnek megúlitúa mely trend felvillantására tanulmányunk első ć́szében is kitértïnk a nem lineáris karriertípusoúćl ónza (Bokor et al, 2009). Az ár kariortpusokról szólva (Bo-

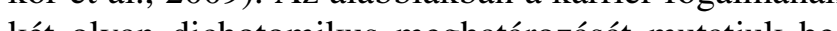
két olyan dichotomikus meghatározását mutatjuk be, amelyek segítenek keretbe foglalni mind az elméleti megközelítéseket, mind a kutatási eredményeinket.

Az első ilyen karrierdefiníciós kísérlet a karrierfogalom idốbeli változását kívánja megragadni, amelyet a karrierértelmezés tágulásával jellemez. A karrier szú- kebb értelmezése szerint a karrier a munkavállaló élete során betöltött pozíciók sora, amelynek része minden munka, amelyet az egyén élete során végez. E karrierértelmezésnek a szakirodalomban sajátságos fejlődés íve van, mely változásoknak megfelelóen a karrierne az egyén szakmai életpályájára vonatkoztatott definíciója így hangzik: eltérô szerepeink sorozata szakm életpályánk során (Bokor et al., 2007).

A tágabban vett karrierdefiníció tovább megy: a karrier részét képezi minden olyan szerep, amelyet az egyén életpal yaja során betölt, tehát a karrier a magénéletet is maǵb foglá ,életstílus-koncepción" (Niles et al. 2002). Amikor az egyén a karrierjéról dö̈t, az ćletében betöttött szerepeinek hatćkony integŕlisát,

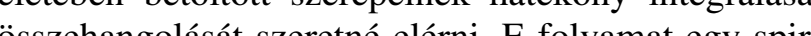

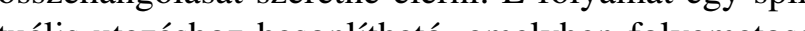
óteḱl . milyen értékeket jelenít meg életünkben (Herr et a 2004; Niles et al., 2002; Patton - McMahon, 2006).

A karrier fogalmának következő, kétpólusú megh tározása a szakirodalomban az objektív és a szubjektív karrier fogalma, melyek tulajdonképpen a karrierutat két eltérő perspektívából mutatják be (Arthur, 1994). A karrier „objektív" meghatározottságát főleg a szociológusok hangsúlyozzák (Koncz, 2002), szerintiik karrier elsősorben a t́r (Kóni munkamegosztásba karrier elsôsorban a társadalmi munkamegosztásba való részvétel inéz ányesilt fogható dolgokban ragadható meg, mint a fizetés, st tus, pozíció (Koncz, 2002. 104. o.). Vagyis az objektív perspektíva a karrier intézményi interpretációján alapszik. Ebból a nézôpontból az egyén karrierútját például így írhatjuk le: kutató - tanár - pénzügyi elemzô bankigazgató - államtitkár - vezérigazgató

A „szubjektív karrier” fogalmán (Gattiker Larwood, 1988) keresztül az egyének képesek megragadni, és értelemteli egészbe rendezni az életüket formáló különféle hatásokat. A szubjektív perspektíva tehát az egyén interpretációja karrierje alakulásáró melynek során képet kaphatunk az egyén motivációiró értékeiról, karriercéljairól. A karrierút ebból a perspek

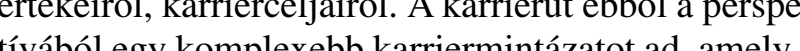
egyén olvasatában megjelenhet például a felnôttté válás történetként.

A továbbiakban részletesen is bemutatunk két, a karrierrel kapcsolatos magatartás változását leíró és magyarázó elméletet: a boundaryless (határválto) karrier és a protean (formaváltó) karrier ${ }^{1}$ elméletét. A határváltó karrier az objektív nézốpontot jeleníti meg (Arthur, 1994; Sullivan et al., 1998), mely inkább szervezeti perspektívából vizsgálódik (Sullivan, 1999), a szubjektív perspektívához pedig a formaváltó karrier elmélete kapcsolódik, melynek keretei közöt az egyén alkalmazkodóképessége és önirányítása kap hangsúlyt. E két elmélet alkalmas arra, hogy a karrirmagatartást az objektív és szubjektív perspektívábó megvizsgáljuk, valamint a karrierdefiníciókkal és azok változásával kapcsolatos elméleti elófeltevéseket felnagyítsuk, és ezekre a kutatási eredményeink tükrében reflektáljunk

\section{határváltó karrier elmélete}

A karrier természetének megváltozását a legtöben (Arthur, 1994: DeFilippi - Arthur, 1994; Sullivan, 1999) a szervezeti struktúrák megváltozáśb́́t és a 1999) a szervezeti strukturák negvaltozásából és a Sullivan és ársi (1998) szzint napjink szetik le. Sullivan es tásai (1998) szerint napjaink szervezetei

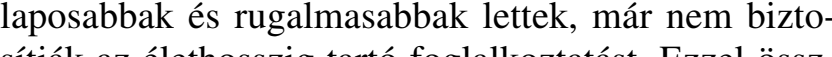
sitják az élethosszig tartó foglalkoztatást. Ezzel összhangban a szakirodalom szerint a munkavállalók igénye lojalitásukért már nem a bér és munkabiztonság, hanem fejlódési, illetve tanulási lehetőséget várnak el teljesítményük ellentételezéseként (Sullivan et al., 1998). Ráadásul a munkavállalók karrierigényeit már nem feltétlenül képes egyetlen szervezet kielégíteni (Nicholson, 1996, in: Koncz, 2002), s fordítva, a szervezetek folyamatos változásra való képessége a munkaerő megújulását is megköveteli ${ }^{2}$ ami a munkahelyváltánok gyakorisáǵban is tetten érhetô. Ezek a trendek hazána is jellemzók: a szervezetváltás gyakoriśga megnott az elólt évelben (Ko czás gyaÉp Eppen ezêr indokolt az elmélet keret alkalmazása gy magyarországi karrierkutatásban is, noha az elmét megállapításaival több ponton is vitába szállunk a utatási eredményeink alapján.

A határváltó karrier DeFilippi és Arthur (1994) meghatározásában olyan munkalehetôségek sorozata, amely túllép egy adott munkáltató keretein, illetve a megszokott foglalkoztatási kereteken: a munkakörökön és a megszokott családi és foglalkozási szerepeken. Sullivan (1999) a határváltó karriert a következókkel jellemzi: (1) foglalkozási határok átlépése, (2) szervezeti határok átlépése, (3) foglalkoztat́si viszonyok jelentéś́n megúltoź́ (új típún pszichológiai jzergiai szer(6) megnövekedet szerepe, (5) szerephatárok átlépése, (6) szerepeken belin aranyok átendezése. Jelen kutatásban ezekre a jellemzókre építve, de jelentósen újraértelmezve határoztuk meg azt a hat, objektív szempontú karrierváltástípust, melyek elemzésünk fókuszába kerültek. Ezeket késóbb részletesen is ismertetni fogjuk

Sullivan (1999) a határváltó karrier jellemzését a tradicionális karrierrel szembeállítva adja meg. Eszerint a határváltó karrier esetén a siker mércéje a fizetes, az elóléptetés és státus helyett most a pszichológi-

\title{
VEZETÉSTUDOMÁNY
}


ailag értelmes munka; a karriermenedzsmentért való felelősség az egyénhez került a szervezettól; a karrie mérföldkövei pedig nem az életkor függvényében, h nem a tanulási pontok mentén határozódnak meg. Fe tételezi továbbá, hogy az egyéni karriermintázatok két fő faktor befolyásolja: a kompetenciák transzferálhatósága és a munka belsố értéke. A kompetenciák transzferálhatósága alatt azt érti, hogy a korábban megszerzett tudás mennyire vihetố át más szervezethez, illetve más karrierpályára. A munka belső értékét pedig az egyén önmegvalósítási törekvéseivel, belso pedig az égyen ónécel, az autonómiár és kihívás való törekvésével jellemzi. Az ideáltipikus háríńló valo törek vésével jellemzi. Az idéltipikus hat karriert az egyén alakítja, amelynek feltétele a kompetenciák

Az elméletet alkotók (Sullivan et al., 1998) magu is megjegyzik, hogy a határváltó karrier koncepciója szervezeti szempontú vizsgálódásra teremt lehetôséget, míg a formaváltó karrier koncepciója a szubjektív perspektívából azt vizsgálja, hogy az egyén szempontjábó milyen jellemzókkel bír az újszerú karrier. Azonban határváltó karrierelméletekben az objektíve megfigyelhetố karrierutakban bekövetkező változások magyarázatához szubjektív elemek is kapcsolódnak. Teh például a szakmaváltást - az intézményesiilt karrierútváltást - összefüggésbe hozzák az egyén ön kanrierút(a) tási torekvéseivel és a siker jelánén megvaltozá sával. Ezen ơsszeftgések feltêteleźse meglehetósen leegyszerúsitó megallapitásokhoz vezet, tobbek közö a határváltó magatartás és a karriermotivációk kapcsolatát tekintve. Kutatási eredményeink alapján látni fogjuk, hogy a motivációk feltárása és az összefüggése megállapítása korántsem ilyen egyszerû́.

A formaváltó karrier elmélete

A formaváltó karrier fogalmát a határváltó karrier elméletéhez hasonlóan a tágabb gazdasági és munkaerôpiaci változásokból vezeti le a szakirodalom, továbbá szintén a pszichológiai szerződés megváltozását han sźńlyozza bár ennek bemutat́áć́s megváltozását hangsúlyozza, bár ennek bemutatásában eltérő hangsúlyok tapasztalhatunk (Mirvis - Hall, 1994). A pszichológi szerződesst a tranzakcionális, illetve kapcsolati szerz dés fogalmai mentén ragadják meg, amit eredetileg társadalmi szerződések típusaira dolgozott ki MacNeill (1980 in: Hall - Mirvis, 1995). A tranzakcionális szerződés lényege a meghatározott periódusra szóló pénzbeli csere a munkáltatóval, amely során a munkavállaló speciális készségeit alkalmazva, speciális feladatokban nyújtott kielégítô teljesítményeért kompenzációban rêszesül. Ezzel szemben a relációs szerződés nem idôhò̃ kötött, sokkal inkább egy folyamatos kapcsolatot létesít az egyén és a szervezet között. Mind monetáris, mind nem monetáris juttatásokat tartalmaz, úgymint kölcsöôs lojalitás, támogatás és karrierlehetőségek.

Mirvis és Hall (1994) a formaváltó karrier felé való elmozdulást úgy értékeli, mint a relációstól a tranzakcionális felé való elmozdulást, vélhetôen a szervezetnél eltöltött idó rövidülése okán, noha a párhuzamot részletesen nem indokolják. Megengedik ugyanakkor, hogy a jövő szervezeteiben mindkét fajta szerződéstípus előfordul majd: lesznek, akiket partnerként kezel a szervezet és lesznek, akikre pótolható erő́forrásként tekint majd. E púrhuzam azo pótolható

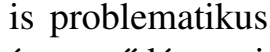
leegyszerüsító. Egyfelóll a rövid távú szerzódéses viszonyból még nem következtethetünk arra, hogy milyen az egyén és a szervezet viszonya: extrinsic vagy intrinsic (Herzberg, 1987) motivációra épül-e. Felmerül a kérdés, vajon a karrierváltások magyarázatára alkalmas-e a pszichológiai szerződés vizsgálata? Következtethetünk-e ezek tartalmára és ez alapján a mögöttes karriermotivációkra?

Hall és Moss (1998) hét pontban foglalják össze a formaváltó karrier jellegzetességeit, amelyek lényegét röviden bemutatjuk. A legfontosabb megállapításokat az egyén magatartáából vezetik le: a karriermenedzsment itt kiź́rólag az egýn felelóscége, autonóm cselek-

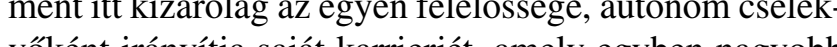
Vokent irányítja sajat karrierjét, amely egyben nagyobb

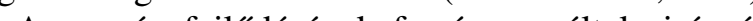

Az egyen fejlodésenek forrása az általa irányított folyamatos tanulás, amely lehetóvé teszi a környezeti vátozásoknoz való alkalmazkodást, illetve a karrierváltásokat. A megszerzett tudás és ismeret jelentősége bban áll, hogy az egyén képes hasznosítani ezeket a következố karrierciklusban, integrálva az önmagáról alkotott profiljába. A tanulás azonban itt ennél többet is jelent, a folyamat lényege a kéthurkos tanulás (Argyris 1977), amely során az egyén a magatartását a mögöttes elvek és értékek felülvizsgálata során változtatja meg, azaz a cselekvési stratégiák mellett a mögöttes motivációk normák is megváltoznak. Ez a tanulási folyama magas szintú öniog

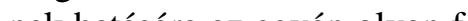
mek melyek hozzajárulnak onmegvalósitási vágyainak megvalósítá1998) Ez uszoss, 1998) a pszichológiai siker elérését értik, amely az élet egfontosabb céljainak eléréséból fakadó büszkeség és a személyes teljesítmény érzése. Olyan célokról van szó, amelyek személyesen fontosak a munkavállalónak, és ô maga túzte ki, nem a szülók, mentorok, a szervezet vagy a társadalom jelölte ki számára (Hall, 1996). Az egyén képes e célok felismerésére, megfogalmazására, az ezekben bekövetkezô változások észlelésére, valamint az étékrendje, motivációi és az aktuális munka közötti kohézió megteremtésére. Így nem elvárás tehát többé, hogy a szervezet kapujában hagyjuk a személyes életünket, értékeinket és passzióinkat, hanem lehetôvé válik, hogy a teljes énünkkel jelen legyünk munkában (Hall - Moss, 1998).

Az egyén karrierhez való viszonyának változása kovetkezó elmozdulásokat eredményezi: a know-how felól a learn-how felé, a munkabiztonság felól a foglalkoztathatóság felé, a szervezeti karrier felól a formaváltó karrier felé, a munkahelyi én" felól az , tegrált én" felé. Mindez a szervezet old" f́ćĺl az „itegrált én" "ó önmegvalóstés tok nyújtását kívánja meg. A karrier így a tapasztalatok, kompetenciák, tanulmányok és identitásváltáso (Toarniczky, 2009) élethosszig tartó sorozata. A karrier rövid tanulási görbékból áll (Hall, 1996), amelyen a „karrieréletkor” számít, nem a kronológiai életkor. A karrierciklusok (az egy foglalkozási helyzetben eltöltött idô) sokkal rövidebbek, amelyeken a felfedezés kipróbálás, megalapozás és kiválóság szakaszai követik egymást (Hall - Moss, 1998).

Mint látható, a formaváltó karrier elmélete olya munkavállaló képét rajzolja elénk, akinek a karriervátásai a kéthurkos tanulási folyamat eredményeképp ö azonosságot, pszichológiai sikert keresve jönnek ótre,

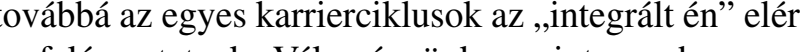
ez azonban ez egyénrôl rajzolt kép idealisztikus: a karrierváltás magy rázatâhoz korântsem elegendó az ônirânyító, autonóm és felelôsségvállaló egyên feltételezése, hiszen a váltás egyén irányításán kívül álló események hatására is bekövetkezhet. Az intrinsic motivációk által vezérelt egyén képe ráadásul nem egyeztethető össze a tranzakcionális szerződés tartalmával és az egyénre vonatkozó feltételezéseivel sem. Felmerül továbbá a kérdés: a pszichológiai siker érzése csak a belsó motivációknak megfeleló cékitúzések esetében értelmezhetó, vagy pedig a materialis célok eléréséból is fakadhat (Sargent - Domberger, 2007)? Kutatási eredményeink alapjón látni fogju ó egyéni jellemA sokkal szinesebb képet mutatnak.

A formaváltó karrier ideáltipikus képét némileg árnyalja, hogy a karrierváltás nehézségeinek tárgyalás is megjelenik a szakirodalomban (Hall - Moss, 1998). Az elmélet alapján a formaváltó karrier megvalósít sához két alapvető képességre, metakompetenciár van szüksége az egyénnek: alkalmazkodóképességre és identitásváltozásra (Hall, 1996), mely utóbbi késôbbi publikációkban már önismeretként szerepe (Hall - Moss, 1998). A nehézségeket e kompetenciák hiányával magyarázzák.

VEZETÉSTUDOMÁNY
Alkalmazkodás önismeret nélkül. E két készség kigészíti egymást, hiszen önismeret nélkül a környezethez való alkalmazkodás olyan reaktív folyamat, melynek eredményeként az egyén értékei és karriercéljai közötti összhang felborulhat (Hall - Moss, 1998). Ez tulajdonképpen - a kéthurkossal szemben - egyhurkos tanulást jelent, mivel a környezet kihívásaira az egyén a cselekvésének módosításával reagál, de nem vizsgálja a mögöttes céljait, értékeit vagy a probléma (alkalmazkodási kényszer) mögött meghúzódó mélyebb okokat (Argyris, 1977). Igy fordulhat elo, hogy laki a munkájában ugyan pszichológiai siker hogy . péchis cencon amikor az

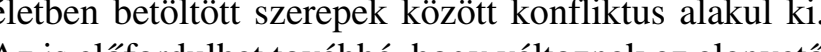
Az is elôfordulhat továbbá, hogy változnak az alapvetố êrtékeink, céljaink, melyekhez hozzá kell igazítani kariercéljainkat is.

Pszichológiai költségek. Míg sokak számára a formaváltó karrier az önmegvalósítás szabadságát rejti magában, addig mások számára éppen ez a szabadság és megnövekedett felelősség lehet ijesztő. Különösen a külsó támogatás - pl. szervezeti karriermenedzsment - hiánya okozhat nehézségeket a munkavállalók számára A formaváltó karrier nyúitotta szabadság kezeléséhez tudatosság és személyes felelősségvállás

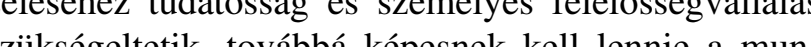

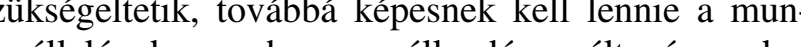
kaválalónak arra, hogy az álandóan változó munkaencer egy koherens önképpé integrálja. Ennek hiányában a formavâltó karrier céltalannak tünhet, és a különbözố eletben betöltött szerepek közötti fragmentációhoz vezethet (Mirvis - Hall, 1994): az „integrált én” helyett kialakul egy „munkahelyi én” és egy „magán” vagy „valódi én”, azaz különböző szubidentitásokra töredezik a személyiség. Következésképp egyre több ember keresi az értelmet a munkán kívül az életében, hogy elkerülje a pszichológiai kudarc tapasztalatát (Mirvis Hall, 1994), a szakirodalom szerint azonban nem ez az üdvözitố út.

Mirvis és Hall (1994) szerint fontos tanulmányozni továbbá a tranzakcionális szerződés kényszerének öltségeit, vagyis azt, hogy a munkavállalók biztonság ránti igénye nem kielégített, illetve a karriertervezést gy bizonytalan környezetben kell végrehajtaniuk, küló segítség nélkül. De ugyanilyen fontos megvizsgál, milyen különbséget jelent a kényszerból, illetve az ,ént válostot het jelent a kényszerbó, illetve az z adaptációs kényszer és az autonóm egyén cselekvési szándéka összeütközésbe kerülhet. A karrierváltás körülményeinek befolyásoló hatására kutatási eredméneink jól rávilágítanak majd. 


\section{Perspektívák kavalkádja}

A következókben röviden a bemutatott két elméle re reflektálunk a perspektívák és a karrierértelmezések tükrében. Összegezve láthatjuk, hogy a határváltó karrier elmélete inkább a karrier objektív perspektívájá ból való bemutatására alkalmas, hiszen a karrierváltás intézményi, illetve szervezeti tényezók megváltozásán keresztül ragadja meg, mint például a foglalkozás megváltozása. A formaváltó karrier elmélete pedig a karrierváltást szubjektív nézópontból tárgyalja, és arra keres magyarázatot, hogy az egyén motivációi, értékei, cálitúzései, készségei és képességei hogyan befolyás, tûzései, készsegei es képessegei hogyan befolyásolja a karrier alakulását. Azonban mind a határváltó, min a formaváltó elméletekben keverednek a perspektívák amelynek következményeként téves következtetése születhetnek az ujszeru karrierrel kapcsolatban. Ilyen például a határváltó karriertípusok elkülönítése a belsó és külsô motiváció, illetve a szervezeti és foglalkozási identitás mentén (Sullivan et al., 1998), amelyben például a karrierváltást, illetve a munkahelyváltást foglalkozási identitás erôsségével magyarázzák. A formaváltó karrierelmélet hasonló ellentmondása, hogy a munkahelyváltás környezeti szükségszerúségéból vezeti le az önmegvalósitás és önirányítás megjelenését a karrierben, és nem fordítva Kutatási eredményeink alapján látni fogjuk, hogy az egyén karrierfelfogásána

dentitás bevonása az elemzésbe, mely az előfeltevésrendszer tisztázatlanságára utal. A formaváltó karrier elmélete ezzel szemben a tág karrierfelfogást tükrözi. Az elmélet utal például a pszichológiai siker szerepére, amely az életünk során betöltött bármely szerep kapcsán kitúzött életcélok elérésébôl fakadhat, továbbá a különböző szerepek integrációjára és a „fragmentált én" pszichológiai költségeire is felhívja a figyelmet.

Az elméletek kritikája és pontosítása után a következő́kben olyan elemzési keretet kínálunk, amellyel célunk e két perspektívából látszó karrierjelenségek tudatos kezelése, a bevezetett fogalmak és magyéz tupontośt́ és az ugyancsk kerek tekint katok definíciókra való reflexió.

\section{A karrierváltási folyamat elemzése}

A kutatás megkezdésekor a karrierváltás első meghatározását az objektív perspektíva alapján, az intézmény formákban bekövetkező változások mentén alakítottuk ki, amelyre a mintaválasztás is épült. Az 1. táblázatban bemutatott - a cikk elsô részében is tárgyalt (Bokor et al., 2009) - objektív karrierváltási formák végleges és pontos meghatározása több lépésben zajlott, egy iteratív, már az elemzést is magában foglaló folyamat eredményeképp.

vizsgált határátlépó karrierváltásáso

\begin{tabular}{|c|c|}
\hline Határváltás neve & Meghatározás \\
\hline $\begin{array}{l}\text { Munkaeró-piaci státus } \\
\text { megváltozása }\end{array}$ & $\begin{array}{l}\text { Mozgás az egyes státusok között: alkalmazott, egyéni vállalkozó/szabadúszó, üzleti vállalkozás } \\
\text { tulajdonosa, választott tiszztségviseló, kivonuláss a munkaerópiacról }\end{array}$ \\
\hline Szektorváltás & Mozgás az üzleti, a közigazgatási, közszolgálati és civil szféra között \\
\hline Szakmai terület váltása & Új, a korábbitól lényegesen eltéró szakmai tudást, know-how-t igénylố tevékenységi területre lépés \\
\hline $\begin{array}{l}\text { Munka és magánélet } \\
\text { arányainak átrendezése }\end{array}$ & $\begin{array}{l}\text { Olyan lépés, melynek eredményeképpen lényegesen átalakul a munkára, illetve a magánéleti } \\
\text { szerepekre fordított idó, figyelem mennyisége }\end{array}$ \\
\hline $\begin{array}{l}\text { Munka és magánélet szerepek } \\
\text { újradefiniálása }\end{array}$ & $\begin{array}{l}\text { Olyan lépés, melynek eredményeképpen jelentősen megváltozik a munka vagy magánélet szerep } \\
\text { felfogása: pl. duális karrierból az egyik fél inkább támogató, kiegészitó keresóvé válik; karrierjére } \\
\text { koncentráló egyedülálló a váltás eredményeképpen családot alapít }\end{array}$ \\
\hline Karrierszünet tartása & $\begin{array}{l}\text { A fő́allású munkavégzés tartós, szándékos szüneteltetése, különböző célokkal: pihenés, tanulás, } \\
\text { egyéb tevékenységek végzése }\end{array}$ \\
\hline
\end{tabular}

és karrierhez kapcsolódó magatartásának vizsgálatára, az összefüggések magyarázatára ezek az elméletek csak részben alkalmasak.

Az elméletek mögött meghúzódó karrierértelmezésekre az elméletek által a vizsgálatba bevont tényezók ból következtethetünk. A határváltó karriernél bemutatott hat karriertapasztalat-típus kizárólag szervezeti vonatkozásokat tartalmaz, amely szúkebb típusú karrierértelmezésre utal: a karrier során betöltött szerepek sorozatát tudja megragadni. Zavaró ugyanakkor az

Az elemzés során továbbléptünk; a szubjektív perspektívát érvényesítve az egyének interpretációjára voltunk kíváncsiak saját karrierjük alakulásáról, amit a naraiviv interjú technika és elemzési eljárás tett lehetôvé. A karrierváltás folyamatának elemzéséhez a továbbiakban tehát egy szubjektív megközelítésen alapuló tipológiát kínálunk, mely mintázatok az interjúszövegek tartalom- és strukturális elemzése alapján rajzolódtak ki. Az elemzés fókuszában a következő öt fó kérdés áll: 1) Mi a váltások kiindulópontja, legfóbb mozga- tórugója? 2) Milyen tényező́ket mérlegelnek a döntés meghozatalakor? 3) Milyen szakaszokban megy végbe a váltás? 4) Mire ad választ, megoldást a váltás? 5) Hogyan élik meg a váltási folyamatot? Azonban a kiindul definíciónkat sem tévesztjük szem elől, a karrierváltás történetek elemzésével az objektív, határváltást megragadó karrierváltást kívánjuk magyarázni.

A kérdések mentén a karrierváltási folyamatok lehetséges magyarázatait hozzuk létre: elsố lépésben mintákat - elhagyás, keresés és átlépés jellegú minta - a kotva törekszünk a részletes leírásra és magyarázatr vábbgondolást segító narratív értelmezésekre is. Megkívabbgonást segtôn ezrative séreljük megragadni a valtási tortenetek kiindulópontjait, fo dramaturgaít, meghatấozó szakaszait. A minták tehát egyaránt otvozzik a narratív és a tartalmi elemeket, amelyekben feltúnó eltéréseket fedezhetünk fel, így figyelmünket a karrierváltási mintázatok különbségeinek megragadására és értelmezésére fordítottuk.

\section{Elhagyás jellegú karrierváltások}

Az elôzó cikkünkben bemutatott alcsoportok elemzése kapcsán szembetúnő volt, hogy a multiszervezeteket elhagyó felső vezetók karrierváltása elsősorban „nem” mondásként, a korábbi, hagyományosnak tekinthetố karrierpálya elhagyásaként értelmezhetô. Ók elôször lezárják karrierjük addigi szakaszát, így nem a vágyaikra vagy egy új lehetőségre mondanak ,igen”-t. A történeteikben az elhagyási döntés kap fôszerepet, ez fogalmazódik meg bennük elôször. Majd egy következô szakaszban, sokszor hosszabb idô után találják meg továbblépés irányát.

A kutatás során vizsgált váltásokat nézve a karrierváltások közel felét az elhagyások történetei teszik ki Az elhagyás jellegú karrierváltási mintában a karrierváltási folyamat az elhagyásról való döntéssel, kényszer jelleg esetén a helyzettel való szembesüléssel indul, amely idóben is hosszabb folyamat. Jellemzóen részletesen, meghatározó, érzelmekkel telített élményként mesélnek erról az alanyok. Az elhagyáskor még nem tudják, hova lépnek tovább, csak azt tudják, mit és miért hagynak ott, minek szeretnének hátat fordítani. Az elhagyást feltünő́en sok esetben karrierszünet követi, ami ebben a mintában a leggyakoribb, jelentősége pedig - a többi mintától megküilönböztető módon - abban áll, hogy ekkor alakítják ki az alanyok az új irányt, készítik elő a következó lépésüket.

A minta jellemzését az elhagyás mozzanatána elemzésével kezdjük, elöször az elhagyott karrierállomás és az elhagyás indokai, valamint a továbblépés irányai közötti összefüggéseket bemutatva, majd az el- hagyásról szóló szövegek narratív érdekességeit felvillantva. Utána a váltási folyamat második szakaszáról, a kanrierszunnetrốl adunk áttekintést, kiemelve ezen váltó minta kapcsán fontos következtetéseket.

\section{Elhagyás - elsó fordulópont}

A karrierváltási folyamatban két lépés, állomás túnik kiemelt jelentôségúnek: az elhagyás traumatikus fordulópontja és a karrierszünet, amely egyfajta második fordulópontként az új alternatíva kialakítása mellett sok esetben az elhagyás és újrakezdés feldolgozását is lehetóvé teszi Ahoz hogy ezt megértsük, écouását is lehetógéleszi Azoz, hogy eat negétruik, érdemes megvizsjaln a a corrierpálya jellemzőit, a döntések lönböztettïnk . Eszempontok mentén négy almint

1. Kiábrándulás a hivatásból, a választott szakmából

Azok a váltások, amelyek során az alanyok a pályaválasztással megkezdett, jellemzően hivatásuknak tekintett szakmát hagyták ott, mind elhagyás jellegú döntések. Ezek az alanyok a pályajjuk elején olyan szakmát választottak, amelyet hittel és örömmel végeznek, és amely értékválasztást is jelent, így az elhagyás nehéz, érzelmileg megterhelố döntés a számukra. Az elhagyások magyarázatainak gyökere fóként a társadalm átalakulások szakmákat érintó háśsaiban keresendő, amelyek követkén teket fo kôvetkencenyeként az alanyok hiányérzefeket fogalmaztak meg, de mindemellett a hivatáshoz fúzódó személyes viszony átalakulása is megjelenik. Ezen elhagyások jellemzó okainak a magyarázatai a övetkezók

Szakmák, szektorok presztízsvesztése

Különösen a rendszerváltozás hatására egyes szakmák, szektorok társadalmi presztízse, egzisztenciateremtó képessége megváltozott. Ez sok alanyunkat késztetett szakmájának elhagyására, azzal együtt, hogy legtöbbjükben az elhivatottság megmaradt, vagy legalábbis nosztalgikusan tovább él, de ez nem volt elég a maradáshoz.

Ezt nem tudom, de ez annyira bennem van a mai napig is, hogy én a leszerelésem napját tragédiaként éltem meg. Tehát az pont egy olyan élethelyzet volt. amikor a hivatástudaton kívïl semmi nem szólt amellett, hogy én a seregben maradjak. Tehát se a saját fejlódésem, ugye tanulni nem engedtek el, se anyagilag nem érte meg, azonkívïl bizonytalanná vált. Folyamatos átszervezések, tömeges leszerelés, tehát nem tehette meg az ember akkor és én is úgy éreztem akkor hogy hivatás ide vagy oda mikor egyetlenegy észérvet sem tudok már mellé tenni, hogy miért maradjak én katona? (Balázs) 
Ilyen terület a katonaság, ahol a biztos egzisztenciát a leépítések veszélye és a kevesebb fizetés váltota fel; a tanári pálya, ahol felerősödött a megbecsülség hiánya, a növekvő terhelés és a változó elvárások mellett. Az államigazgatásban a rendszerváltozás elôtt dolgozó alanyaink történeteiben a szervezetek állandó átalakulása, a politikai hatások és személyi változások nehézségei jelentettek kényszerpályákat, és a „régi gárdával" való azonosítás sem mindig volt jó ajánlólevé a továbblépéshez. Továbbá természetesen a politikához közeli tevékenységek elhagyása a rendszerváltohoz közen tevé zás körny a csalódások és a valamely politikai irányvonallal való azonosítás félelmei szerepelnek indokként. A külkere kedelem szembetủnő átalakulása is megjelent néhán alanyunknál, amelyet az addig kiemelkedó kereseti és utazási lehetôségek után a privatizáció, a megszúne sek, a szervezeti átalakulások konfliktusos szakmáv változtattak. A rendszerváltozás okozta presztízs- és egzisztenciavesztések egyrészt anyagi problémakén másrészt csalódásként csapódnak le a váltók életében. - Egzisztenciális problémák

A legtöbb váltásnál a társadalmi hatások következményeként jelentôs egzisztenciális problémák állnak elô, végeredményben a megélhetési problémák, pénzhiány és az cbból fakadó biztonsághíny állnak a változmegfelelố külső́ körülménye miatt hagyuk e hivatúsukat, s nem belső elhatározấ vációk játszank föszerepet? vációk játszanak fôszerepet.

Az ötödik évig eljutottunk odáig, hogyha ezt akármennyire csúcsra járatjuk vagy felfejlesztjük, azt a fajta egziszzenciát nem tudja nekünk megadni, ami mi magunknak szerettïnk volt megteremteni hossz távon. (Márton)

Fél évvel a diplomaszerzés elótt elkezdtem keresni. Ez abból állt, hogy elmentem iskolákhoz, mondtam, hogy itt van egy pályakezdó biológia-kémia szakos lelkes tanár és kellek-e? (...) Protekcióm nekem nem volt, és még akkor igencsak a protekciós alapon ment az állás... Egyetlenegy új iskola nyitott, hó, mondom halleluja, majd oda biztosan fölvesznek, nem, nen halleluja, majd oda biztosan folvesznek, nem, nem
vettek föl. Aztán mondom jó, akkor elmegyek napközis vettek fol. Aztán mondom jo, akkor elmegyek napkozis
tanárnak, hát Istenem... Ha már bent van az ember tanárnak, hát Istenem... Ha már bent van az ember állást. Napközis állást sem kaptam, aztán mondtan jó, nekem jó lesz egy helyettes napközis állás is, csak munka legyen. Azt sem kaptam, megsértódtem, azt mondtam, ha nem kell a magyar társadalomnak eg ilyen jól kvalifikált, ügyes, talpraesett, lelkes taná akkor nem leszek tanár. (Enikó)
Csalódás, szakítás", kiábrándulás

A csalódás egyrészt a közeggel való viszonyból fakad, kiábrándulnak munkahelyükboól, kollégáikból, fónöökikból, illetve a hivatással, szakmával kapcsolatos elképzeléseikből. Ez már a személyes hitet és képességeket is érintố csalódás, erre példa az az alanyunk, aki rádöbben arra, hogy sosem lesz a legjobb (élsportoló), ezért szakít az addigi életével. Az elhagyási döntéseket tekintve ezek a váltások jellemzóen hosszabban érlelődtek az alanyokban, és érzelmileg is nagy traumákról számoltak be.

Nagyon nehezen hagytam ott a pedagóguspályá Tehát, hogy én tényleg próbáltam ezt így toldozgatni(Dóra)

Mert igazából, hogyha ide ezt be lehet szúrni, ezt a gondolatot, már amikor beadtam, már megbántam, hogy elhagyom a hadsereget és azt a miliót, amiból én ott kikerülök. Ha ma lehetett volna, már visszacsináltam volna, nem adtam volna le semmit, se az egyenruhám, se az akkori életemet, nagyon megbántam már akkor. (...) Hát nagyon nehéz, mert ezzel mindennap együtt kel, fekszik az ember még mind a mai napig is. Tehát én álmodok még mindig a repüléssel. És ahogy halad elöre a kor, ahogy telik-múlik fölöttem is az idó, és az önismeretnek egy bizonyos fokára eljut az ember, egyre jobban kapaszkodik vissza azokhoz a gyökerekhez, ahol jól érezte magát. Vagy úgy gondolja, hogy neki való volt. Es bármi áron próbál azokhoz visszajutni. (Patrik)

Ezek a váltások inkább kényszer jellegúek, és a fóként személyes kudarcokból, kiégésekből származó esalódások hosszas mérlegelésében születô döntések. Az érzelmi telítettséget az adja, hogy az új alternatía gyakran az addigi értékrendszertốl való elfordulást, vagy az azzal való ellentmondásba kerülést hozza: például a katonák az ország védelmére tett esküjüket, a tanárok a gyermekek nevelésébe vetett hitüket hagyják ott. Ezek az elhagyások az életpálya elején zajlanak, ami két szempontból is meghatározónak látszik: egyrészt az életpálya korai szakaszában az egzisztenciateremtés elsődlegessége miatt is kényszerpályára kerïlnek, másrészt a

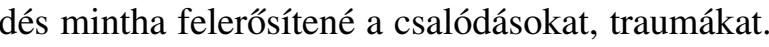
Anyagi szempontok mentén választva lépnek tovább, ami önmagában egy másfajta prioritást jelent a munka-hivatás kapcsolatában. A következó karrierállomás így a biztonságot és anyagiakat jelentố multinacionális szervezet, néhány esetben saját vállalkozás alapítása Mivel a szakmájuktól teljesen eltérố területet választanak, így nemcsak szektorváltás (jellemzően államiból üzletibe), hanem szakmaváltás is bekövetkezik.

\section{2. „Deal” felmondás}

Az ide sorolt váltások az adott karrierállomás megkérdójelezéséból fakadnak, és a munkával, közegg kötött 'deal' felmondását hozzák. A 'deal' olyan üzletkötést jelent, amelyben a munkáért járó előnyökért munkavállaló vállalja az azzal járó befektetéseket. Ezek a váltások nem kényszerból születnek, az alanyok önszántukból hozzák meg a döntést. Az elôző almintától eltéróen ezek a karrierállomások nem az első szakmát, munkahelyet jelentik, hanem a második, néhány esetben már a har jik karierállomást. Három eset kiveben unk itt, a kivé(a) betöltött vezetón pozíciók szerepelnek, amelyeket az alanyok elóre elhatározott idóre és keretekbe vállalnak, azaz a 'deal' elốre megkötik. Ezek mindössze 3-4 évre szólnak, míg az ide sorolt multielhagyásokkal átlagosan 8-10 éves karrierszakaszt zárnak le alanyaink.

A multik világába belépók (ez esetben vezetók) a státusért, jó egzisztenciateremtési lehetôségért, sikerélményért, tanulási és előrelépési lehetőségekér vállalják a multimunka hátrányait, nehézségeit. Tehát nem érték-, vagy érzelmi alapon elkötelezettek e karrierpálya iránt, nem hivatásként tekintenek rá, nem keresnek ügyet mögötte. A multival kötött szerződésnek ez a fajtája hasonlóságot mutat a tranzakcionális szerződéstípussal (Hall - Mirvis, 1995), itt azonban a tranzakciónak nem csupán materiális elemei vannak, hanem a határváltó karrierhez elengedhetetlen kompetenciák megszerzése is részét képezi. Elhagyás okként a szövegekben a „deal" konfliktusos elem szerepelnek, amelyek valamilyen aktuális eseményhe kötődően kerülnek felszínre. Ugyanakkor sokszor az egymásnak feszülố elemek mélyebben húzódó konfliktusokat takarnak, amelyek miatt egy adott pillanatban tarthatatlanná válik a megkötött 'üzlet'. Az érzelm elköteleződés hiánya ellenére a 'deal' felmondása, az addigi karrierpálya lezárása mégsem látszik egyszerúnek, az interjúalanyok hosszan mérlegelnek, és a váltást traumatikus élményként élik meg. Nézzük ezeket a jellemző elhagyási okokat.

- Multinacionális szervezetekhez való viszony -értékkonfliktusok

A multiszervezetekhez való viszony az ezredford lótól kezdôdóen fokozatosan változik: a társadalmi és gazdasági szerepükról, az egyénre gyakorolt hatásukról való gondolkodás egyre ellentmondásosabbnak tủnik. Feltúnő a különbség a rendszerváltás utáni időszakba történt és a késốbbi, akár a közelmúltban zajló belépése történetei között: az utóbbinál az indoklás terjedelmesebb és sokszor társadalmi-gazdasági összefüggésekbe helyezett magyarázatokat, kritikai gondolatmeneteket is tartalmaz. A multiban való szerepvállalás ma már nem képzelhető el anélkül, hogy erról komplex, elfogadható magyarázatot ne alkossanak alanyaink mind a külvilág, mind önmaguk számára

Az elhagyások magyarázataiban rendre feltúnnek az értékeket, ezek összeütközését megjelenító szövegek, amelyek arról tanúskodnak, hogy ezek az alanyok felsővezető́i pozíciójukban értékkonfliktusokat élnek meg. Kiábrándulnak, nem ehhez a világhoz tartozónak érzik magukat.

Elốrevetítettem, hogy mi lenne, ha 45-50-60 éves 年 volt szimpatikus, a hogyan ók a foglyaivá váltak ennek a rendszernek a saját véleményiaket ugy tirnt, hogy a vesztik, és csak azt nézik, hogran kell kiszolgálni. Hogran kell azt mondani amit hallani szeretne az a felsúbb vezetó azért, hogy benne maradhasson a andszerben. Biztos, hogy az összes nugy multicégnél nagyon hasonlo, kialakult egy önzáródó folyamat. Amikor az ember egyre feljebb lép, egyre többet keres, és az életforma mindig követi ezt mert az enber mindig annyit költ, amennyit keres. Le allabbis az életbölosességem ezt mutatja. És aztún nem lehet abból kiszállhi, mert akkor megvette a hízat amire felvette ant [hitelt]. A gyerekei magániskoliba jar nak stb. És emiatt ha akartak, ha nem az emberek benne vitak ás meneteltek elore ás engre inkibb be-

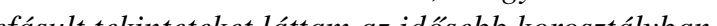
(Zoltán)

Es akkor arra akartak kötelezni, hogy a 3000 fös cégból, hât most vannak 800-an, de 600-at céloztak meg, hogy ezeket mind kuldjem el. Es akkor én mondtam, hogy nem. Ezt én mar nem csinalom végig. Ezt nem. En itt felépítettem. Az egészet átalakítottam, itt minden ment, itt ezt én nem fogom megcsinálni. (Emese)

Az egyre kritikusabbnak és ellentmondásosabbnak đúnó viszony a multielhagyások kapcsán erốteljes eltoló és magyarázó erô. Mindemellett sejthetô, hogy az elhagyás okai a határozott kiábrándulást és kritikát megfogalmazó alanyainknál más, szervezeti és egyéni tényezôkkel is összefüggnek.

Magánéleti konfliktusok

A 30-35 év közötti életszakasz jellemzően a muna-magánélet kapcsolatának újragondolási idôszaka. A magánéleti konfliktusok eróteljesen a karrierváltás rányába hatnak azoknál a nóknél, akik üzleti szervezetben töltöttek be vezetôii pozíciót. Azok, akiknek még nem volt tartós kapcsolatuk, kiemelték, hogy a karrierjük megnehezítette, vagy pedig lehetetlenné tette annak kialakulását. Ugyanakkor a kilépés közvetlen 
kiváltó oka többnyire egy személyes vagy szervezet konfliktus, amely az érzelmi lökést is megadja a döntéshozatalhoz. Csak az új lehetőségek közötti választáskor erősödik fel döntési szemponttá az a kérdés, hogy olyan helyet keressenek-e, ahol a karrier lesz prioritás, vagy olyat, ami nagyobb lehetőséget kínál teljes családi életre.

A párkapcsolati konfliktusokon túl a gyereknevelés kapcsán is említenek elhagyásra ösztönző tényezóket. A női vezetók esetében azok, akiknek van gyermekïk, mind utalnak arra hogy anyai szerepük betöltését nehezi-

tette a karrierjük, és hogy gyerekeik támogatták a váltást.

Ók [gyerekeim] azért visszafogottan voltak lelkesek ezért a karrierért. Fóleg úgy, hogy a férjem is azért elég sokat dolgozott. Aztán egy kicsit úgy job ban megértették, de ók nagyon-nagyon kapacitáltak arra, már évek óta, hogy mi a fenéért dolgozom? Próbáljak kevesebbet dolgozni. Csak hát, ugye, nagyon nehéz ezt megcsinálni, hogy mert ez ilyen bináris. Te hát vagy ott vagy az igazgató, és akkor ennek minden elónyével és hátrányával együtt. Vagy akkor a sajâ munkahelyemen most mi van, legyek osztályvezetó Azért az nem úgy van, hogy akkor most feleannyit dolgozom. (Margó)

- Önismereti folyamat, életpályaközép-válság Az elhagyásra ható egyéni tényezók talán egyik legizgalmasabb és sokszor legnehezebben meghatározható kategóriájába tartoznak azok a belső dilemmákból, önismereti felismerésekbôl kialakuló döntéshozatali folyamatok, amelyek - akár az életpályaközép-válság jelenséghez köthetốen - váltásra késztették alanyainkat. Ezek a megfogalmazások sokszor nem a döntéshozatali történeteknél, hanem a visszatekintô, értékelő szövegekné bukkantak eló, valamint - hasonlóan az eddig felsoro tényezókhöz - más elemekkel összekapcsolódva értelmezhetőek. Az interjúk során azokat a kérdéseket, dilemmákat, szövegrészleteket értelmeztük önismereti folyamatként, amelyek a „ki vagyok én?” identitást érinto kérdést feszegetve explicit felismeréseket tartalmazna

Az életpálya-közepi válságra jellemző elakadások gyakorta a karrier és a magánélet teljes újragondóx́ hozzák. Az elhagyó karrierváltásokban mindez két lepésben megy végbe. Elösz̈r döntés szilletik arról, hogy az, amit most csinálok, biztosan nem ́n arón, hogy lami más az ćn utom”, biztosan nésóbi fogyok, kialakul az ú an ", majd egy késóbi folyamatban ke munkahelyeken (többségük nagy szervezetekben vezetốként) dolgoznak az elakadás megfogalmazásako ahol teljes eróbedobással „pörögnek”, majd belefáradásról, a kihívás, energia, hit elvesztéséről beszélnek.
A „kipörgés” olyan dilemmát erősít fel számukra az életpálya középső́ szakaszában, amelynek következté-

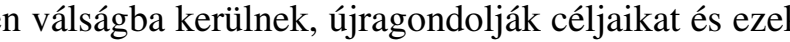
elérési módjait. Feltúnő, hogy többségében a férfiakná találtunk erre példát, ugyanis a nói alanyok hasonló elakadásai a magánéleti konfliktusokkal összefonódnak, elsősorban női, anyai szerepükkel kapcsolatos kérdésekben gyökereznek.

Szóval én közben kiszálltam a business életból és azt mondtam, hogy tartok egy úgynevezett midlife service"-t Usye, amikor az ember azt mondja, hogy nahát most már lassan negyven felé vagyok, meg kell nézni hogy hogyan tovább mit csináljunk mivel foglalkz-

Megoldást a kilépés hoz számukra, és a váltás explicit módon a válaszok megtalálását célozza. Elhagyási okként jellemzően az önismerethez szükséges tér és idố megteremtése szerepel, ami gyakran karrierszünetet von maga után, hiszen pontosan a kilépés utáni „semmi" hoz válaszokat ${ }^{4}$

A „deal” felmondások között néhány kivételtól eltekintve multielhagyásokat találhatunk. A magánéleti konfliktusok eredményeḱpp - jellemzően a nókná - mind az életvitelüket mind a prioitŕs a nókné

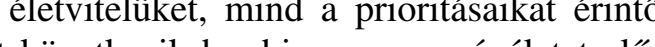
fer veluán mult felsó vezetóból szabadúszók, civil szektorban munkát jestor jellegét" és irányát jól magyarázzák - az elóző tanulmányban bemutatott (Bokor et al., 2009) - a korosztályok sajátosságai.

A 'deal' felmondásból hozott multielhagyók egyik korosztálya az idősebb generációból kerül ki. Ók egy korábbi karrierpályáról, már vezetôii pozícióba átlépve kezdték multikarrierjüket. A váltások jellemzője az éré́kalapúság, azzal, amit tesznek önmagukon, túlmutató háśst akarnak elérni, valami nem csak üzleti szempontú éćket alkotni. Mivel ćk a , rendszet" változtathatan( a élik meg, 'gy az egész üzleti vilagnak hátat fordítaak, igy szektort és szakmát is váltanak. A legfiatalabbak a puról indulva gyorsan jutnak magasra. Ok is értékalapú kritikát alkotnak, de csak a multiközegre, az alkalmazotti létre mondanak ,„nem”-et. Az új alternatívával a multik „rendszerszintứ” kritikájához kapcsolódóan más szektorban próbálnak egyéni szintú konstruktív megoldásokat találni, újszerú, értékalapú kapcsolódásokat letrehozva. Az elhagyott karrierpálya tehát egyben az új érték és életforma választásának fordulópontja, 8-10 eves multiéletet hagyva a hátuk mögött.

\section{Karrierívzárás}

Ezek az alanyok mind nagy szervezetben, egy alany kivételével multiban, felsővezetói pozícióban, 40 felett hozták meg elhagyási döntéseiket, annak a (középsô) korosztálynak a tagjaiként, akik már a multinacionális szervezetekre jellemzó üzleti kultúrába szocializálódnak, pályakezdő pozícióból indulva korán magasra ível karrierjük. Az ezredfordulót követố küls változások azonban leginkább a multinacionális cégek nél dolgozók esetében hatottak az elhagyó döntésekre Lelassult ezeknek a szervezeteknek a növekedése, sốt,

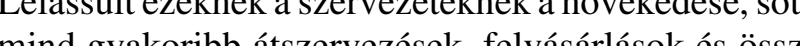
mind gyak, olvadăsok, konzzolidaciók egyre tỏbb vezetó számá teremtettek közvetlen vagy közvetve fenyegetó kényszerhelyzetet. Egyre nagyobb eséllyel kerülhettek be veszélyeztetettek körébe, hiszen a fiatalokkal szembe drága munkaerôt jelentettek, és már kevesebb továbbfejlôdési potenciállal is rendelkeztek. Kézzelfoghat realitássá vált, hogy a multikarrier nem tart örökké, és az innen kilépók nem feltétlenül kapnak hasonló karrierlehetőségeket. A „nem ettől a cégtől megyek nyugdíjba” realitása egyre többek számára bővült ki a „nem ebből a szektorból, karrierpályáról megyek nyugdíjba" tapasztalattal.

A záruló karrierív jellemzó dilemmákat okoz a felsố vezetốknek: végére értek egy emelkedô karrierszakasznak, végighaladtak azokon a pozíciókon, amelyek bejárhatók voltak számukra. A váltás az esetükben leginkább kényszer jellegú, egy adott ponton a karrierívüi lezárulásával szembesülnek: kénytelenek új karriert kialakítani, hiszen nem tudják felsővezetối pozícióba folytatni pályájukat.

Most azért egy 53 éves nó ma Magyarországon, a munkaeropiacon, hat az katasztrofa. Tehát lehet tgy hivni. Tehát az, hogy 53 éves marketinges nö utä nem fognak kapkodni, ez körülbelül, én ezzel számoltam. (Margó)

Tehát én ezért voltam a $X$ cégnél, imádtam ott, és még amikor ott voltam, azt hittem, hogy sose les vége. (Bence)

47 éves voltam. Szóval azért ebben a korban már nem olyan könnyü elhelyezkedni. (Tibor)

A kilépést azonban nemcsak szervezeti okokk magyarázhatjuk az ő esetükben, hanem személyes tényezőkkel is. Az egyik az életkor, amellyel néhán interjúalany összeköti váltását, mivel ugyan a kor novekedésével a veszélyeztetettség érzése nő, de megjelenik a lehetőségként való felfogás is: itt az utolsó pillanat, amikor még van értelme valami újba belevágn A másik eltoló tényezó a karrieréletkor, amely a kani eríven, a multiszervezetnél eltöltött idốt jelenti (Hall Moss, 1998). Azok például, akik a rendszerváltás után kerültek be az akkor felépüló multinacionális cégekbe és gyorsan előrejutva 12-16 évet dolgoztak felsôvezetôként, végigélhettek „mindent”, és megteremthették azt az egzisztenciát, amelyet célul túztek ki. Igy tehát elérték a kiválóság szakaszát (Hall - Moss, 1998), ahol az adott karrierciklus véget ér. Mindezek a tényezốk yitottabbá teszik a vezetôket az új lehetőségek keresésére.

Új karrierjüket is az üzleti életben alakítják ki, szinmindig a korábban megszerzett szakmai/vezetôi tudásukra és kapcsolatrendszerükre alapozva kezdenek izleti vállalkozásba, vagy lépnek tanácsadói pályára. A kényszer jelleg adja itt az átfordulás jelentôségét, számukra a trauma jóval negyvenéves kor fölött, átlagosan tobb mint 13 évnyi multiélet után, nehézkes újrakezdésként következik be

\section{. Sikertelen alternativából továbblépés}

Itt olyan váltások szerepelnek, amelyek elsố mozzanata szintén az elhagyásról való döntés: az alanyok az adott karrierállomás sikertelenségével, a munkalehetớség megszúnésével (befulladó projekt, vállalkozás, megszúnố szervezet) szembesülnek, tehát kényszerhelyzetekre keresnek megoldást. Jellemzóen iövid 1-5 évig tá ka

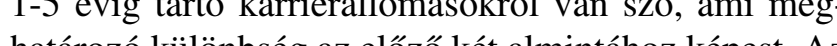
hatrozó elhagyás jellegú mintában a válások közel harmada sorolható ide, ugyanakkor a kényszerhelyzet megélése eltéró intenzitású. Azok az alanyok, akik érzelmileg nem kötődtek az adott karrieralternatívához, és az új lehetốség gyorsan kialakult, kevesebb idốt töltöttek a megoldás kialakításával, és a kényszerhelyzetbe sem ragadtak bele.

Néhányan tehát gyorsan és könnyedén találnak megoldást, beérkező ajánlat, vagy az első elgondolás, megkeresett ismerős, ötlet, álláslehetőség révén. Az elhagyások okait és az intenzív megélést vizsgálva látható viszont, hogy a saját ötletre épített vállalkozásokban az viszón hón fón nehézségeikén fog élményt is jelent. Az egyeni vallalkozóvá váló alanyok a nagyobb fugggetlenség, jobb egzisztencia elérése miatt vágtak bele ötletük megvalósításába. Többüknél ez egyfajta kenyszernek is értelmezhetó, nem volt ennél vonzóbb lehetôség számukra. A lépés legtöbbjüknél nagy váltást jelent, korábbi karrierjüktőll gyakorlatilag minden tekintetben elszakadnak. Azonban a vállalkozással járó nehézségekról, az anyagi függetlenség helyett a bizonytalanság felerôsödésérôl számolnak be. Több alanynál szerepelnek olyan megfogalmazások, amelyek 
Az elhagyás jellegú alminták összefoglalása

\begin{tabular}{|l|l|l|l|}
\hline \multicolumn{1}{|c|}{ Alminta } & \multicolumn{1}{c|}{ Mit hagynak ott? } & \multicolumn{1}{c|}{ Elhagyás okai } & \multicolumn{1}{c|}{ Miért határváltás? } \\
\hline Kiábrándulás a hivatásból & Hivatást, választott szakmát & Egzisztenciális problémák, csalódás & Szakmát és szektort váltanak \\
\hline „Deal” felmondás & $\begin{array}{l}\text { „Deal”-tés az ezzel járó } \\
\text { életformát, értékeket }\end{array}$ & $\begin{array}{l}\text { Életpályaközzép-válság, magánéleti } \\
\text { dilemmák }\end{array}$ & $\begin{array}{l}\text { Üzleti közegnek, alkalmazotti } \\
\text { létnek fordítanak hátat }\end{array}$ \\
\hline Karrierívzárás & Felépített felsővezetối karriert & Záruló karrierív & Munkaeró-piaci státust váltanak \\
\hline $\begin{array}{l}\text { Sikertelen alternatívából } \\
\text { továbblépés }\end{array}$ & $\begin{array}{l}\text { Sikertelen vállalkozási ötletett, } \\
\text { rövid ideig múködố projektet, } \\
\text { megszúnố szervezetet }\end{array}$ & $\begin{array}{l}\text { Egzisztenciális problémák, } \\
\text { bizonytalanság, kudarcok, } \\
\text { kényszerek }\end{array}$ & Új szektort, státust választanak \\
\hline
\end{tabular}

a vállalkozói lét nem teljesen szabályos múködéséró

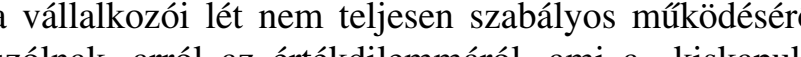
szólnak, arról az értékdilemmáról, ami a „kiskapuk” megjâtszásá és a személyes értékek közötti viszonyt féés valami egészen újba kezdenek bele.

Nagyon nagy teher volt rajtam. És akkor közben bejöttek ezek az adók, személyi jövedelemadó, áfa stb. És akkor úgy döntöttem, hogy én nem csinálom tovább az üzleteket, mert kezdett már nem rentábilis lenni, akkor ilyen nagyon magas kamatok voltak, és akkor eladtam mind a két izzletet. (Viktória)

Nagyon érdekes, hogy emellett a következó pillanatban, amikor beadtam a papírt, hogy én nem szeretnék [katona lenni], ott egy vállalkozást csináltam, amit aztán pillanatok alatt ugyanezt megélve el is adtam. Idézójelben pillanatok alatt, tehát megtapasztaltam, megéltem, csináltam szorgalmasan, de el kellett adni, mert éreztem, hogy én ezzel nem fogok tudni azonosulni. És már akkor is ez az érzés tovább hatványozódott bennem, hogy a vállalkozói világ az egy nagyon kemény, és úgy sakkozni a bérekkel meg a törvényekkel, hogy mindenki a szabályokon belü legyen, szinte lehetetlen. Nekem az nem tetszett. Emiatt is, kilógott nagyon a törvényesség kereteiból, mert hogy máshogy nem lehet nagyjából élni. (Patrik)

Az alternatívák sikertelensége megviseli az alanyokat, személyes kudarcként élik meg, amirôl hosszan beszélnek. A döntésük meghozatalában az is nehézség, hogy a váltások többsége a vállalkozói lét feladását jelenti, aminek végül teljesen hátat fordítanak, de ekkor még nem tudják, mi az, ami felé lépnének. Az elbocsátások is személyes kudarcként csapódnak le, a kényszerú helyzetre gyors megoldásokat keresnek. A sikertele alternatívából való továbblépés iránya így - fớként az egzisztenciális problémák miatt - a biztonságosab alkalmazotti lét, sok esetben a multinacionális szervezetbe való belépés. Ez a tendencia igaz az elbocsátot alanyokra is, függetlenül attól, hogy melyik szektorbó érkeztek.

A 2. táblázat a négy alminta fố jellemzôinek összefoglalását adja az elhagyott karrierállomás jellemzőinek és a fó okok megragadásán keresztül:

\section{Második fordulópont - karrierszünet}

Az elhagyás jellegú váltásoknál tehát az első állomás az elhagyásról szóló döntés meghozatala. A karrierváltás teljes folyamatát nézve azonban még hiányzik a következő lépés, az új alternatíva kialakítása, választása. Ezek irányára és jellegére már utaltunk, azonban még nem esett szó arról, hogy milyen módon születik meg az új karrieralternatíva. Karrierszünet tartása az elhagyás jellegú váltások több mint egyharmadánál jellemzô, továbbá ennél a mintánál a leggyakoribb: az új alternatíva kialakítása és választása (elókészítése) zajlik ekkor.

És hát elterveztem persze, hogy fogom kipihenni. Könyvek felhalmozódtak, olvasás, zene, barátok, boroźs, sportolás, uszoda, tehát ming nen sikeriult teljes mértékhen de tényleg alapvetón próbáltam koncentrálni a saját hedonizmusomra és a hörnyezetre és lapozi a megelózón négy ćven, és a sikerült. (József)

Szóval ez így nagyon nem tetszett, de [végül más ok miatt] követtem el a bungee jumpingot. Mert ezt én ugy hivom, vagy mentalis méregtelenitest rendeltem

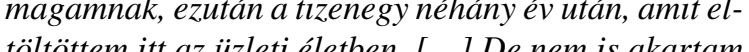
thelyem itt az Uzleti eletben. (....) De nem is akartam elhelyezkedni. Szoval akkor ugy tenyleg vagytam egy

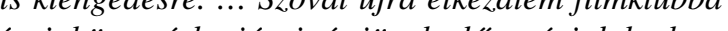
járni, könyvtárba járni, és jöttek eló a régi dolgok az eletemben. (Tibor)

Az elhagyás jellegú váltások közül a „,deal”-t felmondó, illetve a karrierívet záró, többségében multi elhagyó felső vezetóknél messze a leggyakoribb egy hosszabb vagy rōvidebb szunnet tartása. E jelenség mógött két ok lelhetó fel: leginkább e karrierívet elhagyók között merül fel a „megérdemelt” pihenés igénye - ami arra utal, hogy egy megfeszító időszakot hagynak maguk után, másfelốl pedig ốk vannak abban az anyagi helyzetben, hogy egy ilyen jövedelemmentes időszakot finanszírozni tudjanak. Így a mintában azok, akik nem tartanak szünetet, fóként anyagi okokból nem is tehet ezt meg: a hivatás elhagyásakor és a sikertelen alternatívából való továbblépéskor a váltás pont az egzisztenciális elakadásokra jelent megoldást. A karriervátásokhoz többféle céllal és formában is kapcsolódta szünetek, ezek közül az elhagyásokat követô típusokat vesszük sorra.

- Tudatos szünettartás pihenés, feltöltódés céllal

A leggyakoribb formát a váltáshoz kapcsolódó pihenő idöszzk jelenti, melynek alopvetô cólja kip

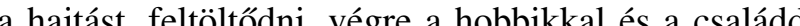
foglalkozni. E csoportba egy kivételével férfiak, mégpedig vezetói pozíciót elhagyók tartoznak. Úgy túnik, ớk csupán egy ilyen radikális lépéssel tudják megteremteni a vágyott idốt a munkán kívüli szerepeikre, tevékenységeikre. A karrierszünet tehát elsődlegesen az akkori szervezetnek és életformának való hátat fordításró szól. Fontos azonban, hogy több interjúalany már elốre tervezve, tudatosan építi be a váltás folyamatába ezt idôszakot. Ezek a típusú szünetek jellemzóen 3-6 hónapig, illetve a következó ajánlat beérkezéséig tartanak. - Tudatos kiszállás a karrier újragondolása, illetve az önismeret fejlesztése céljából

Három interjúalanyunk esetében a karrierszünet fogalma túllép az egyszerú pihenés, feltöltődés fogalmán. Ahogy egyikük utal is rá, itt már az életpályaközéphez kapcsolódó megállásról, a járt útról való lelépésróll, új utak tudatos kereséséról van szó. Akad példa önismeret-fejlesztési célzatú zarándoklatra, vagy hobbiként végzett természetgyógyászatra, amely késóbb foglalkozássá növi ki magát. Ez a típusú szünet hosszabb ideig, akár 1-2 évig is eltart, és a keresés eredményeként a karrierszünet a következő lépés elhatározásával, megérlelt döntéssel zárul.

- Gyes, gyed, mint karrierszünet és potenciális karrierváltás

A gyermeket vállaló nói alanyainknak karrierszünetként volt része ez az idôszak, többségében közvetlen vagy közvetett karrierváltási hatásról lehet beszámo Az otthon töltött idốt ezek a nói alanyok arra használják, hogy újragondolják céljaikat és igényeiket, esetleg képezzék magukat, s így teremtsenek új lehetôséget maguknak. Egy kivételével mindannyian valamilyen önfoglalkoztatási forma irányába indulnak el, tanácsadók vagy vállalkozók válnak belólük.

\section{Az elhagyás traumatikus narrativája}

Az elózôekben az elhagyás mozzanatát és a váltási döntés meghozatalát két irányból mutattuk be: egyrés érzékeltettuik az elhagyott karrierállomáshoz való kö- tôdés eltéró okait, valamint bemutattuk ezekkel összeiggésben az alanyok indokait. Mindemellett érdemes elhagyásról szóló szövegeket narratív elemzés alá is etni, amely érzékletesebbé teszi a karrierváltási folyamat fordulópont jellegét, és tovább árnyalja a döntéshozatali folyamatot.

A narratívák elemzésénél feltúnő a stílus grammatikai homogenitása: a kilépési, elhagyási döntések leírása aktív, első szám első személyü igékkel történik.

És az hogy én ebból kiléptem, az az én döntésem volt. (Ibolya)

De hogy a felmondásomban ez volt, és hát azért mondtam föl, hogy ezzel az emberrel megcsináljam a közös cégünket. És el is akartam távolodni ettól a szakmától. (Tamás)

azt mondtam, hogy, vagy 2002 elején igen, hogy én még egy évet lehüzok itt, a 2002-es lesz az utolsó évem, és utána valami mást keresek, mert nincs már nekem ebben kihivás. Felépült, és nélkülem is múködik. [...] Es azt mondtam, hogy OK, megcsinálom, elmegyek, megcsinálom, és a következó választások elótt én eljövök. (József)

nem tudtam azt mondani, hogy ez csak munka, hanem az volt úgy az életem. ... Tehát én belevittem az érzelmeket meg mindent. És ugye, már amikor állandóan pofont kaptam, akkor az nagyon megviselt. És akkor úgy felmondtam, hogy igazából nem nagyon tudtam, hogy hova fogok továbbmenni, vagy mit fogok csinálni. (Kriszta)

A legtöbb történet alapvető üzenete, hogy a váltók maguk hozzák meg az elhagyó döntést, nem kilépni kényszerülnek. Ráadásul sokszor jellemző a dramatizálás, erơs érzésekre utalás, a döntés nehézségének, terhének megmutatása. Ezek a narratív stílusjegyek azt jelzik, hogy nem triviális, nem természetes lépésekról van szó. Az elhagyási történetek üzeneteit több szinten is lehetséges értelmezni.

Azt tapasztaltuk, hogy a velünk megosztott karriernarratívák magukban rejtik a siker kényszerét, vagyis a fő dramaturgiai felfogás egyfajta romantikus kaland, ahol a főhős sikerre jut a megpróbáltatások közepette, és nehézségek között hoz jó döntéseket. Azt feltételezzük, hogy létezik egy erós belső/külső elvá ás: saját életünk döntéseiben kormányosok, aktívak, erősek legyünk, és pozitív kicsengésú történeteket alkossunk.

Az elhagyási döntésekben való aktív szerep hangmozása azokban a szovegekben is eróteljes, ahol a meséló kényszerekról is beszámol. Kevés elhagyási történetben kapnak ezek főszerepet, az elbocsátás

\section{VEZETÉSTUDOMÁNY}


még „tabu” témának túnik. Sót, ezekben a helyzetekben mintha fontos lenne hangsúlyozni, hogy ez nem az egyén kudarca: a rossz szervezeti körülmények mán nem voltak megfelelőek, és így az egyén akaratáva egybecsengó a történés. A magyarázatokban tehát az alanyok vagy az események passzív elszenvedójekén jelennek meg, vagy a saját szerepüket hangsúlyozzák ,saját hatáskörbe vonva” a külső körülményeket, mintha aktív alakítói lennének ezeknek az eseményeknek is. A kényszerhelyzetek ilyen megfogalmazása arra is utalhat, hogy az egyének megtartík cselekvő- és reaúlóképesśgiiket, ami a pozitív meghiizdéshez reavetốn fontos.

Az aktív szerep hangsúlyozásának egy további lehetséges értelmezése a kudarcok (akár elbocsátások) és a meghozott döntések kognitív disszonanciájának csökkentése, amelyben a kényszer olyan külsố tényező, amelyre az egyénnek nincs hatása. Ilyen példáu néhány szövegben a „sors”-ra való hivatkozás, amely egyfajta determináltságban való hitre utal. A magyarázatok megalkotásával tehát az alany úgy csökkenti disszonanciát, hogy ezzel mind önmaga, mind a hallgatóság számára elfogadhatóvá teszi döntéseit. Mintha az elhagyás aktusa önmagában nem sikerre, illetve aktív szerepre utalna, hanem egy olyan szakadásra, törésre, ami nem megszokott, és inkább kényszerú, problemertkus. Arra következtetionk hogy vélhetôn problematitermészetesek, nen (ankáb gyanúsak a nagy kilepések, karriervaltasok, kott, hagyományos út

A dramatizáltság és érzelmi elemek a váratlanságo is megjelenítik. Mindez azt az értelmezést erósíti fe mely szerint a váltások többsége nem egy hosszú távú terv részei, hanem az adott helyzethez való alkalmazkodás eszközei, amelyeket akkor és ott kell felfedezni, dönteni róluk. Ráadásul ritkán köthetók valamilyen megszokott korábbi karrierhelyzethez, ezért élik meg úgy, hogy magukra maradtak, magukért kell felelôsséget vállalniuk, kreatívnak és kockázatvállalónak kell lenniük. Szembetúnő volt, hogy az interjúalanyokno tartott visszajelző workshopokon milyen gyakran tet-

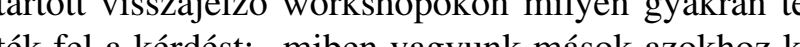

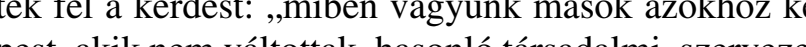

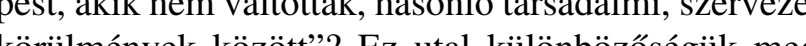
kórésére, az áltónos mintától nú elválás négúk megelésére, az álalános mintatól való elválás nehézségére. Ugyanakkor a legtöbben kiemelték a lépés bátorság és kockázatvállaló hajlamukat. (Ugyanakkor voltak, akik e másságukat inkább terhesnek, akár „betege nek", különcségnek élték meg.)

Végül azt is megemlitjük, hogy ezekben a helyzetekben az alanyok beszámolóik szerint legtöbbször „,valód döntést" éltek meg. Azaz kiléptek a még sikeres kar- rierek esetében is sokszor jellemzố sodródásból, a kizámítható lehetôségek közüli szimpla választásokból Dontöttek, abban az értelemben, hogy elengedtek valait, nem arra mentek tovább, amerre az út kanyarodott, hanem letértek az ösvényról. Onazonosságot éltek meg, nem a készen álló minták közül választottak, hanem maguk alakították saját karrierjüket. Ráadásul a hivatásból kiábrándulók esetében ez a döntés egy korábbi szeméyes választás elengedését is jelentette, ahol a karrierdöntés különösen szorosan összefonódott az identitásuk Lakulásával. Talán éppen ezért ezek a döntések lassan clő́tek meg, egyfajta halmoźdás, telít”ós lassan

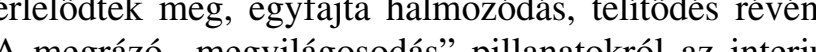
A megrázó „megvilágosodás” pillanatokról az interjú

Ez egyszerúen az volt, amikor egyszer egy tréninen nekem is kellett elóadást tartanom. És éreztem, hogy nem tudok hitelesen beszélni. Szóval felalltam, Sem tudtam azt, amit addig, hogy hittel... Erted? Es akkor azt mondtam, hogy itt most valami elszauadt. Szerencsere ketten volunk prezentaciot tartok, ugyhogy a masik crezte es at ink prenni a dolgot. De

Utána mentem a rendszeres heti megbeszélésre, a Company Day után, a vezérigazgatóhoz, hogy mik a következó feladatok, miben mit kellene, hogy kellene egyeztetni, csinalni. És azt éreztem, hogy amit felirok a kis listamra, hogy mit kellene csinalni, már nincs hozzá kedvem. Es nincs kedvem hozzá, akkor hogy fogok dolgozni? Ha nekem nincs valamihez kedvem, az borzasztó lesz... Es akkor így megszületett bennem: ha nincs kedvem hozzá, akkor ne csináljam. (Judit)

Gyakorlatilag itt kezdtem besokallni egy kicsit, és hát itt kezdtem el mondani, hogy gyerekek, egy szép nap felállok, és úgy ott hagylak, mint annak a rendje... Ami aztán egy szép napon meg is történt egy bizonyos értekezleten, amin szerintem olvasmiket beszéltek és olyan szempontból, ami teljesen helytelen volt. Én felálltam és azt mondtam, hogy én ehhez már nem vagyok partner, és kiszálttam a buliból és azonnali hatállyal felbontottam a munkaszerzódésemet, ı̈bbet nem mentem be. (Jänos)

Az aktív szerep, a sikeresség és dramatizáltság arratíváinak különös ellenpontot adnak az új alternatíva kialakulásáról szóló, többségében passzív szerkezetú megfogalmazások. És bár az értelmezések lehetnek szöveghúek, amelyben elfogadjuk az aktív helyzetalakító, bátran döntố karrierváltók képét; és lehetnek kritikaiak, amelyben a narratíva megalkotásának diszszonanciát csökkentố és a társadalmi elfogadottságot megteremtő funkcióit erősítjük fel, mindenképpen szembetúnố, hogy az elhagyásról szóló szövegek ki- emelt eseményként szerepelnek a karrierváltási történetekben, többségében ez a lépés jelenti az igazi ford lópontot alanyaink karrierpályájában.

Az 1. ábrán a minta narratívájának fó ívét jelenítjï meg, összefoglalva legfóbb állomásait, szakaszait és ezek jellemzöit.
Az elhagyás jellegú narratíva íve

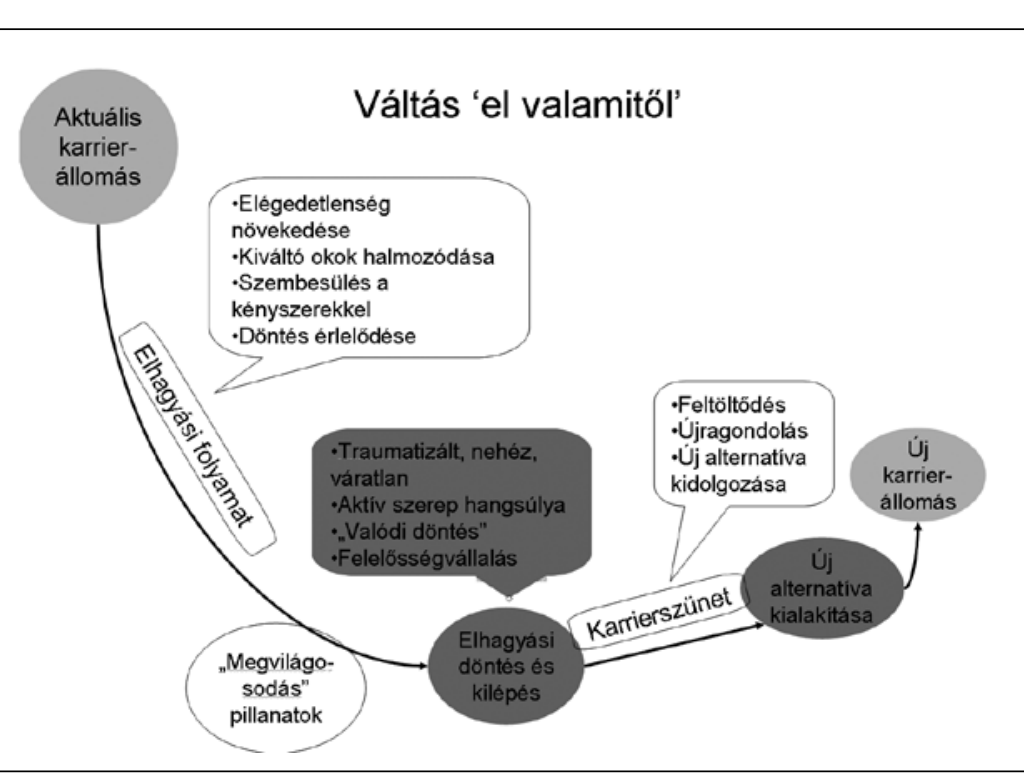

ezt követô lépések már az új irányról hozott döntés következményei, és idốben is szorosan követik egymást. ớt, néhány esetben az új alternatívát párhuzamosan megkezdik az elhagyás mozzanata elótt. Az elhagyáskor tehát ezek az alanyok pontosan tudják, hova lépnek tovább, és azt is, hogy ezzel milyen célokat, vágyakat 1. ábra szeretnének beteljesíteni.

A keresó motívum megértését a karrierdöntéseket meghatározó elképzelések és vágyak eredetét megragadó mintázatok felrajzolása teszi lehetôvé, így a minta jellemzését ezzel kezdjük. Mint látni fogjuk, az alanyok nyilvánvalóvá teszik ezeket az öszzeniggéset, aninek szerét és jelentóségét a váltási folya szert ét és jelentóséget a valtasi folyanatrol szoló történetek narratív jellemzóin keresztül is bemutatjuk.

Gyermekkorból táplálkozó törekvések A kereső magatartás itt az életpálya korai szakaszában elindul, a teljes karrierívet meghatározó, értékeket, motivációkat megjelenító vezérlő motívumokra találhatunk példát. Ezek egyrészt valamilyen szülói ,üzenet” továbbvitelét, vagy a gyermekkori közegból, akár a lakóhelyhez köthetố élményekból táplálkozónan kiala-

\section{Keresés jellegú karrierváltások}

A teljes mintát tekintve a váltások egyharmadánál számolnak be az alanyok olyan váltási folyamatról, amelyben az új alternatíva kialakításáé, kereséséé a fószerep ók valamilyen határozott elképzelés, vágy irányába váltottak, így ezekben a szövegekben az új irányra val „,igen”-t mondás kap hangsúlyt. A váltásról, a döntésról szóló szövegek nem a „mit és miért hagytam ott", hanem a „miért és hova mentem tovább”-ról szólnak. Az elképzelések kialakításának, az új alternatíva keresésének és a választásokkal beteljesülő váoyaknak a történetei ezek A váltási döntés elbeszélése tehát nem to köulményeirôn szól, han az a jestásól, annak indokairól, múltbeli és jelenbeli okairól, a lehetőség k alakításának torténetereôl, a választás mikéntjéról

A keresés jellegú karrierválttási minta esetében a kál

A keresés jellegú karrierváltási minta esetében a karrierváltási folyamat a megvalósítandó vágyak, elképzelések megfogalmazódásával és ehhez kapcsolódóan az új alternatíva kialakításával indul. Ez után következik kiemelt jelentőségú: a vágyak megfogalmazása és az új alternatíva elókészítése jelenti a fordulópontot, az az elhagyott karrierállomásról, annak köriilmán ne az aktuális karrierállomás elhagyása. Itt az elsố lépés kuló motivációk kialakulását és folytonosságát jelentik a karrierdöntésekben. A váltásoknál a döntésekben az alanyok ezeket a vezérló elveket történeteken keresztül fogalmazzák meg: találhatunk előreutalásokat (gyeekkori élmények elő́revetítése), illetve visszautalô magyarázatokat. Ezekben komplex értékrendek tükrözódnek, amelyek adott karrierváltásban meghatározó motívumok. A történetek mellett az értékeket összegzô szövegek is felerósítik ezeket a vezérlő motívumokat.

Az egyik nagymamám az elsó diplomások közé tartozott az országban, a nók között igen. Mert hát azért az 1800-as évek végén nem volt nagyon jellemcsaládja az egy feltaláló család volt, a nagymamám szerint a helikoptert, igen a nagypapám, az ó apukája találta fel, csak ellopták tóle a találmányt. És ezt el is hiszem. O mindenben ilyen erós asszony volt, nemcsak a munkában. Nagy dolog volt például úri aszszonyból munkásasszonnyá válni, és ó ezt meg tudta csinálni. De például 56-ban ó kereste meg a halott gyerekeket. Az egész ismeretségi körben, mert ớ ott lakott a Szövetség utcában. Ment, és kereste, forgatta, ugye, és nézegette a hullakat, és mindenkinek megkereste a gyerekét. (Emese)

\section{VEZETÉSTUDOMÁNY}


ebben aztán nagyon fontos volt a polgármesterség lényegének a megértése, az, amit egy 1876 ban Lukacs Onon református lelkész altal irt $X$ város torténelemkónyvebol êteltem meg, hogy a polgârmesterség lényege nem a kótsegvetés egyensúlya, fontos han hogy vachan a polgarok metellenu fontos, hat hogy waloban a polganok messerekent egy mintát mutassak fel, és egyfajta életet meg érté-
keket. (Péter)

A keresés iránya, célja adott karrierváltásokná szembetưnő párhuzamosságot és folytonosságot mut a gyerekkorból elmesélt történetekkel és az ,„üzenetevel”: egyfajta „példabeszédként” és magyarázatként szolgálnak a karrierváltásokra. Erre a szövegek strukturális helyzetéból is következtethetünk, hiszen a karrierváltási történetekbe, magyarázatokba ékelődnek be ezek a szövegek.

A váltási döntések kapcsán az értékekkel, hajtóerớkkel való szembesülés, tudatosítás, és az ezek mentén való döntés hosszabb és megérlelt foly ezek (1) amely egyfa nak. Azonban az alanyok által megjelenitett értékek es üzenetek nem minden kanierdöntésükben jelennek meg ennyire erôteljesen, vannak olyan váltásaik, amelyekben az elhagyás jellege erôsoodik fel, és csak az új alternatíva kialakításában tükröződnek vezérlő értékeik.

\section{Gátolt pályaválasztás}

Itt a kereső motívum ugyancsak az életpálya kora szakaszában indul, a késóbbi karrierdöntéseket meghatározó törekvések a pályaválasztási történetekben bontakoznak ki. Ennek kapcsán arról számolnak be az lanyok, hogy ott elindult egy fontos szál: kialakul egy vágy é, hogy ot sakma iránt, valamilyen érakul egy

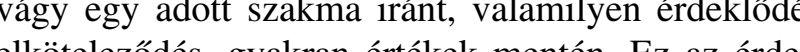
lő́dés azonban gátakba ütközik, melyek az alanyok szüleik tiltásaiból származnak.

Hát igen, ez egy többfordulós játszma volt valóban. Mert többször megtörtek ók [szüleim] engem. (...) Tehát még mindig az ó értékrendjük. Amikor vé gül is teljesen a saját utamat válaszzottam, az talán a pszichológia. Amikor ez a teljes önmegvalósitás, vag hogy mondjam. (Viktória)

Érdekes lehet végiggondolni, hogy a családja az embernek hogyan befolyásolja az alakulását, az enyé met valószínúleg nagyon. Hát az, hogy 17-18 évesen nem pszichologia szakra mentem, annak is van egy családtörténeti vetülete. (Vali)
Így egy másik szakma felé indulnak el, amelyben azonban pár év után nem érzik jól magukat, így 3-5 éven belül új terúletet keresnek, amelyet további 2-3 karrierváltás követ. A váltások okai között mindvégig jelen van egyfajta „nem ez az én helyem” élmény, belefáradás. Kényszerhelyzetek is előfordulnak, de mindvégig bennük van az eredeti elképzelés, így végül az (interjúkészítéskor) utolsó karrierváltásukban ezt valósítják meg. Így a karrierútjukat több kitéróként, ,kísérletként” is értelmezhetố karrierállomás színezi, ugyanakkor a keresés motívuma végighúzódik a teljes karriertörténetiikön: vagy elôn vétássl, vagy az adott karriervátás enarriervaltás jegrán jás, vissegét. Kienellk a vágyott szakmára való rátalákájuk kapcsán „megérkezésról” számolnak be.

Személyesen egy teljesen hasonló utat járok, csak most már magamat kell biztatgatni, hogy még mindig higgyek, amikor az ötödik vagy nyolcadik kudarc é, hogy még akkor is ezz kell csinalnom, és mondom, most úgy kezd beérni valami. (Boldizsár)

A másik, ami érdekes, hogy én ezeket a dolgokat, amikor csináltam, mindegyiket élveztem egy darabig, de azt hiszem, hogy még soha nem volt olyoúrzésem, mint most, hogy megérkeztem. (Vali) A karrierváltásukat elókészítik, tudatos lépéseket
tesznek az új alternatíva felé, így a kitéróként jellemzett korábbi karrierállomásokról éles szakmaváltással lépnek tovább. Azonban az elhagyás jellegú váltásokhoz hasonlóan itt is van szerepe az aktuális karrierállomás eltoló tényezőinek, elégedetlenségnek, belefáradásnak, valamint a váltást lehetővé tevő támogató tényezóknek, mint a biztos egzisztencia és az elókészítést jelentő tanulmányok (akár felnő́tt fejjel, nappali képzésben). Mégis a legszembetúnóbb jellemzóje e váltásoknak az önismereti jelleg, hiszen a gátolt érdeklődések kapcsán egyfajta belső függetlenség elérése, a tiltó üzeneteken való felülkerekedés fontos eleme a vátás létrejöttének. A keresó

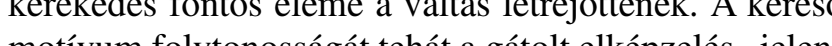
mót" " s feleronodese ad léte "és felerósôdése adja, amely az önmegvalós

\section{Fordulópont, felismerés}

Az előző két mintával szemben a karrierváltási folyamatot az életpálya középsố szakaszában zajló fordulópont határozza meg. Ezek olyan események, pillanatok, amelyek az addigi értékrendben, életvitelben jelentôs átrendezódést eredményeznek, tehát nem a folytonosság, hanem a „szakadás” jelleg hangsúlyos. Ezek az ,igen”-ek tehát útközben születtek. A forduló- pontot jelentố események között traumatikus élménye mellett alapvető átgondolást hozó pillanatok is szerepelnek

És azt mondta, hogy tudom-e, hogy édesanyám rá kos, és hogy már áttétei vannak, csontrákos, és hogy hát egy évet saccol az orvos, hogy annyi van még nehi hátra. Szóval ez volt az a helyzet, amikor megint elén jött, hogy igazából mi az élet lényege, és igazából mi az igazi értékek. És akkor még itt semmi nem történ karrierszinten, csak énbennem eló kezdett jönni az a érték. (Sára)

A lufi az az volt, amikor a házasságom elkezdett teljesen konkrétan inogni. Akkor nagyon sokat gondolkodtam azon, hogy én hogy is állok most ezzel. (...) És egyszer csak ez egy kipukkasztható dolog, így az mondja [a férjem], hogy nem szeretne többet egyedül lenni. (...) Ha jobban megnézem, amikor máso boldogan potyogtatják és szülik a gyerkócöket, akkor nekem miért kell hol az egyik, hol a másik cég menedzsmentjében találnom magam? Valójában ezt a nố utat akarom én tényleg tiszta sziviból, vagy csak éppen, mert hogy ez múködik, ezért vagyok benne? (Judit)

Ekkoriban volt a coach-om az XY, és ó is segitett. Tehát ez egy vezetóképzó́ coach volt, hogy én jó vezetó legyek, és egy idó után rájöttünk, hogy én tudok jo vezeto lenni, meg tudom oldani a konfliktusokat, é hogy nem ez a legnagyobb baj, amir meg kéne oldani, hanem az, hogy mit keresek itt. Volt egy ilyen pillanat. (Tamás)

Sok olyan szöveget találtunk, amelyek önismereti dilemmákról, az identitást is érintő kérdések feltevésér és megválaszolásáról szólnak: Ki vagyok én? Mi az én dolgom? Ezek a dilemmák a váltási döntések szövegeibe ágyazottan jelennek meg, és a válaszok ,igen”-ekhez vezetnek. Valamilyen érdeklődés erősödik fel, vagy valamely prioritást rendezik át, végül elhivatódnak a vâlasztott új értékrend, életforma felé. A váltási folyamat tehát egy magánéleti eseménnyel indul, amely hatásá önismereti kérdéseket tesznek fel az alanyok, a válas pedig a kiervát tén is átépnek a váltás abbend mivel nemcsak a munkaszerepeikról, hanem a magánéleti szerepeikról és e kettố kapcsolatáról is döntenek.

\section{Karrierötle}

A keresés jellegú karrierváltások között találhatun olyan váltásokat, amelyek egy konkrét karrierötlet megvalosításáról szólnak. Olyan célok ezek, amelyeket az alanyok tudatosan meglépnek, de sem - az elôzó mintákhoz hasonló - „elózményekról”, sem önmegvalosítást, identitást érintố kérdések, dilemmák felmert- léséról nem beszélhetünk . A karrierváltás tehát azért következik be, mert az alany olyan karriercélt, ötletet fogalmaz meg, amelyet valamilyen határátlépéssel tud megvalósítani: így lesz például vállalkozóból államigazgatási szektorban felső vezetô, rádiózó színésznőbôl vendéglátós, autószerelóból újságíró-riporter.

És megmondom ószintén, hogy tekertem arra, ami nekem a problémám volt, hogy nem volt igazán kapcsolati tókém. (...) Tehát megtanultam a szakmának a csínját-bínját. Nagyon sokat készültem. Egy ujjabb egyetem volt az az idószak. Nem voltak igazán kapcsolataim. Es hát azért mindenhol egyébként a világon, szerintem, de Magyarországon aztán persze különösen, vagy itt talán még nagyon sokat jelent. És ezért én megpróbálkoztam azzal, tehát rástartoltam, igazgatósági tag szerettem volna lenni az uj $X$ cég [államigazgatás] igazgatóságában. (Róbert)

De akkor elkezdtem állást keresni, hogy jó, akkor ahhoz egyszer volna kedvem, hogy nyissak egy kavé zót, vagy ilyesmit, és erról eléggé határozott elképzelésem volt, hogy az hogy legyen. És gondoltam, hogy az nem jó, hogyha úgy nvitom meg a kávézót, hogy fogalmam sincs a vendéglátózásról tudom, hogy van egy papírom róla kell gyakorlat. És akkor hogy, hogy nem, hát elkezdtem keresgélni, és tulajdonképpen az elsö helyre vettek föl. (Erika)

Ezen váltások többsége párhuzamos tevékenységként indul, tehát az alanyok a karrierötletet a fóállásuk mellett, párhuzamos karrierként valósítják meg. A keresố jelleget az adja, hogy az ötlet nem kényszeroól születik, hanem saját belsổ elhatározásból, maguk lakítják ki az új alternatívát: „,eret engednek” adott céljaiknak, vágyaiknak, elképzeléseiknek. Így tulajdonképpen egy új, általuk létrehozott karrierállomáson próbálják ki magukat. A váltási folyamat a karrierötlet kialakulásával indul, majd egy határozott lépéssel megkezdik az új tevékenységet, elókészítettséget a párhuzamosság jelent.

A 3. táblázat a keresố jellegú váltások fố csoportjait Atatja a kereső motívum eredete és következményei mentén.

\section{A keresés történeteinek narrativája}

A keresés jellegú karrierváltásokat a keresés eredetével, és ebból következóen a váltások folyamatának és ơvetkezményeinek leírásával jellemeztük. A következő narratív jellemzók a minta egyedi jellegzetességeit agyítják fel, foként a keresés eredetének és folyamatának jelentôségét illusztrálják, ezzel egyben magyarázatul is szolgálnak a fent bemutatott négy csoport hasonlóságaira és különbségeire. 
A keresó́ jellegú alminták összefoglalása

\begin{tabular}{|l|l|l|l|}
\hline \multicolumn{1}{|c|}{ Alminták } & \multicolumn{1}{c|}{ Mit találnak meg? } & \multicolumn{1}{c|}{ Keresés okai } & \multicolumn{1}{c|}{ Miért határváltás? } \\
\hline $\begin{array}{l}\text { Gyermekkorból } \\
\text { tálálkozó törekvések }\end{array}$ & $\begin{array}{l}\text { Meghatározó értékek, elvek } \\
\text { képviseletét }\end{array}$ & $\begin{array}{l}\text { Az elvek, értékek képviselete a } \\
\text { munkában }\end{array}$ & Jellemzóen szakmát váltanak \\
\hline Gátolt pályaválaszzás & $\begin{array}{l}\text { Vágyott szakmát, } \\
\text { önazonosságot }\end{array}$ & $\begin{array}{l}\text { A kezdeti elképzelés } \\
\text { megvalósítása }\end{array}$ & $\begin{array}{l}\text { Éles szakmaváltás (gyakran szektort } \\
\text { és státust is váltanak) }\end{array}$ \\
\hline Fordulópont, felismerés & $\begin{array}{l}\text { Új értékeket, elveket - új } \\
\text { életformát }\end{array}$ & Elakadás, trauma & $\begin{array}{l}\text { Több határt is átlépnek (szektor, } \\
\text { szakma, munkaeró-piaci státus) }\end{array}$ \\
\hline Karrierötlet & A karriercél elérését & $\begin{array}{l}\text { Valamilyen karriercél } \\
\text { megvalósitása }\end{array}$ & $\begin{array}{l}\text { Új területre lépnek: szakma- vagy } \\
\text { szektorváltás }\end{array}$ \\
\hline
\end{tabular}

- „Elórejelzó” és „,visszatekintô” magyarázatok A keresó karrierváltások történeteinek közös jellemzóje, hogy a döntések megszületésének megfogalmazása egyes szám elsổ személyben történik. Az új irány magyarázata a hangsúlyos, az alanyok mintha azokra kérdésekre adnának választ, hogy „Miért ez választo tam? Miért fontos ez nekem?". A válaszok megfogalmazásában felfedezhetô egy érdekes idóbeliség: a magyarázatokban az alanyok visszanyúlnak életpályájuk egy korábbi eseményéhez. A magyarázatok tehát nem csak az adott váltás „,idejét” érintik, hanem az életpálya korábbi eseményeit is tömörítik.

Na most, mint emlitettem, 68-ban egyetemista voltam még tehát ez még a mindenfaita karrier kezdete elótt, részt vettem egy chartres-i zarándor kezott megkaptam a hivatásomat, csak nem akandádon, Mindig kitaláltam valami kifogást hogy miért ne így ment 20 évig. A 80-as években, amikor a Cartierban megtapaszaltam, nem is a Cartier-ban a Enrico Garnize révén találkoztam a rosszal a gonosszal ebben a világban, akkor rádöbbentem, hogy nem kellene nekem visszamennem ahhoz amire nekem hivenevan, és nem ezekkel a dolgokkal foglalkozni, de hát mondom nem, elhalasztottam a döntést, és azonkívil ebból a kalandból adódóan volt jó pár tízezer márkús adósságom, és azt le akartam dolgozni. (Ferenc)

Ezeknek a „visszatekintő” magyarázatoknak funkciója leírható a folytonosság megalkotásának igényével: az alanyok a ,jelenidejứ és a korábbi karrierés életeseményeik között egyértelmú párhuzamot és osszefüggést terentenck. Az eletpalya korabi esemenyeivel való kapcsolat néhány alanynál egyfajta „elórejelzésként" már az interjú elején, az ún. absztraktba (Riessman, 2008) megfogalmazódik. A következő idézetek olyan absztraktok, amelyek tartalmára késóbb az alanyok többször visszautalnak váltásuk magyarázatánál, illetve olyan dramaturgiai elemeket tartalmaznak, amelyek ugyancsak ismétlódnek a későbbi megfogal- mazásaikban. Az elsô idézet olyan alanytól származik, rozó és fontos viszonyítási pont karrierváltásainál, a második alanynál pedig a szülókkhöz való viszonya, a továbbtanulás elakadása jelent visszatérő magyarázati elemet.

Ameddig én vissza tudok menni, alapvetóen nagyapáig, és mondjuk azon át lehet sietni, de ilyen szempontból van egy érdekes dolog ebben az egészben, édesapám, már ahonnan ó indult, és ahol én folytattam, az nekem marha fontos, meg a gyerekeim. (...) Onnan indulnék, hogy én egy falusi srác vagyok eredendóen, mind a mai napig büszke erre egyébként, sajátos értékrend szerintem, ami falun az embert éri, szemben a várossal, noha egyébként 14 éves korom óta a városban élek, de amit szereztem 14 év alatt, az nekem egész életemre meghatározó élmény volt. (Róbert)

Mindig nagyon jó tanuló voltam, de nem tanultam. És hát akkor én úgy gondoltam, hogy nem akarok tanulni, meg nem érdekel ez engem, az általános iskola után szakmunkásképzóbe mentem. És szüleim választották ezt, tehát nem én választottam. Ó́k választották. (Viktória)

Az indító szövegrészek, az absztraktok narratív vizsgálatakor a következő kérdésre keresünk választ: az elso gon a kovelkezó kérésre keresink válasze A kerés jellegú vát a szerepe a késóblekben? A keresés jellegư vátások kapesán tehát feltünő, hogy az indításban olyan tơrténetet mesélnek el, illetve olyan értelnezó meggogalmazásokat találhatunk, amelyek késóbb kiemelt jelentőséget kapnak: az alanyok a karrierváltások magyarázatainál visszatérnek ezekhez a történetekhez és értelmezésekhez. A folytonosság megalkotása még szembetúnőbb, amikor a eljes interjúban nyomon követhetô az indító történet, onértelmezés ,,sorsa”: az interjúk fő fonalának tekinthetó az alany által kiemelt elakadás, dilemma megolakinek a gyökerek, az értékrend, a család meghatá-

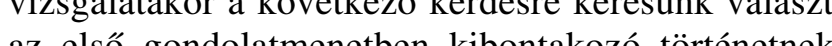

dása. Az így létrejövő fó motívum a teljes karrierívet átfogja, néhányan ezt egyfajta „sorsszerúség” megfogalmazásával, illetve az ismétlódések kiemelésével erősítik.

És akkor találtam ki, hogy elmennék pszichológia

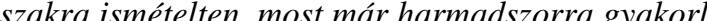
tilag, és mit tesz isten, sikerült. (.) Valahol a vágyak valahol az eredet, in sittatis aktor is felszinre tönck, ha gátakat vetünk eléjük. (Vahi)

Mintha lenne néhány olyan minta az életemben meg ilyen életfeladat, meg ilyen mély dilemmák, amiért az ember egész életében így küzd, és vagy jut vel valamire, vagy nem. És ez tök jó. És azt is mondhat nám neked, hogy ez az egész, attól szép az ember éle te, hogy belekényszerül ezekbe a nehézségekbe, amitól ha meghátrál, de ha mégis fölvállalja valahogy, akkor kénytelen megoldani, vagy saját határain tullépni, na. És magyarul tanulni új dolgokat, és ez igy van, igen. (Boldizsár)

- „Saját ut" narratíva

A folytonosság - amelyet az alanyok az életük különböző eseményei közötti kapcsolatok, összefügoések megmutat́ś́val teremtenek meg -értelmezhtő az önazonosság megalkotásaként, identik azonen: To me vebben: Toarniczky, 2009). Itt érdemes felfigyelnün a visszatekintố és elórejelzô magyarázatok tartalmár A magyaráz tóténetek jellenzón gyermekkorból, letve az életpálya korai szakaszából idézódnek fel: korai gátak, a szülók beavatkozása és a gyermekko hatásoknak az identitás alakulasára is jelentốs hatása van. Amikor a szülói minta elfogadottként jeleni meg a pályaválasztás történetében, akkor az identitás a szüló́któl hozott értékrend mentén alakul. Ilyenkor a késôbbi életútban állhat eló intenzív identitáskeresés. A szülói tiltások esetében viszont az alakuló identitás kerül veszélybe, ilyenkor jellemzôen már a pályaválasztáskor megkezdődik az identitáskeresés, amely a késốbbi nagy számú váltásban is lecsapódik. Úgy túnik, hogy a szülói tiltásba ütköző alanyoknál nagyobb intenzitással indul el az identitáskeresés, mintha ösztönösen az önmagukká válásért harcolnának, még akkor is, amikor a szülối tiltás már nem áll fenn. Az önismereti jellegú karrierváltások tehát összefügghetnek pályaválasztással, a szuiló́k hatásával, valamint az identitás alakulásával, amely a késốbb bekövetkező ford lópontok, felismerések kapcsán is megjelenik: az alanyok a karrierjuk egy adott pontján kezdik kialakitani, átformálni az identitásukat. A közös szál az önismeret, az útkeresés, amelyet egyfajta „saját út” kereséseként, „önismereti út” járásaként írnak le.
Ha szerencsés lennék, kvázi legyen ez a vágyaim megfogalmazása is, akkor hamarabb megtaláltam megfogalmazása is, akkor hamarabb megtala
volna azt az utat, amit végig kell járnom. (Vali)

Nagyon sok szerencsével - a szerencse miatt van, hogy járhatom ezt az utat, és nem kell kényszerpályákon, anyagi vagy egzisztenciälis, erkölcsi vagy

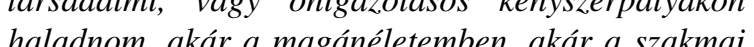
életemben. Nagyon sok ember egész életében próbél a szilei elort igan sok enber agesz alertben probal alaminek. (Péter)

A valódi békesség irányába halad az életem, igy érzem. Kis nagyképüséggel lehet bölcsességnek is hivni, a bolcsesség iranyába. Megbékélsz azzal, hogy a világ ilyen, te ilyen vagy, ilyen korlataid vannak, és rendben vagy, ez irányába. Abba az irányba, hogy egyre újrafogalmazod magad és egyre, mert abban mégis van valami konvergencia. Tehát nem az, hogy most ez az egesz, hanem, hogy valami megiscsak halad, valamilyen irányba, ami te magad vagy. (Boldizsár)

- Dramatizált történetek és értelmezések

Az elhagyás jellegú mintához hasonlóan a váltásokról szóló történetek dramatizáltak, jellemző az érzelmekre való utalás, azonban ezek nem az elhagyás nehézségeiról, hanem a döntést magyarázó folyamat megéléséról, meglépéséról és az elért eredményról zólnak. Az érzelmek, a drámai hangvétel a folytonoságot biztosító történetekben, a fordulópontokról, felismerésekról szóló szövegekben és az utólagos értelmezésekben is jelen vannak. Ezeknek a szövegeknek maga a „mesélô” ad kiemelt hangsúlyt azzal, hogy a történetek, értelmezések részletesek, sokszor az interjú ritmusától elütő́en hosszabbak és árnyaltabbak. Az alanyok tehát mintha „felnagyítanák” mindazt, ami fonos: ezeken a történeteken keresztül megismerhetőek, megérthetőek.

Egy másik értelmezésben úgy is tekinthetünk ezeke, mint az önmaguknak szóló megerősítésekre, hiszen a „saját utat járó, örömtelien megérkező” karrierváltó bizonyára jó döntéseket hozott, így kívülrốl sem ,ítélhetünk" másképp, mint hogy boldog, sikeres emberek. A karriernarratívák sikeralkotó jellegére az elhagyás jellegú mintánál is utaltunk. Ugyanakkor itt a fó dramaturgiai vonás nem egy nehéz helyzetben hozott jố döntés, hanem a belülrớl táplálkozó elhatározás „útja”, amely kitérókkel, elakadásokkal és felismerésekkel teli, de végül beteljesülést hoz. És valóban, ók értelmet keresnek és találnak abban, amit és ahogyan tesznek, 'gy a karrierdöntéseikben, a munkájukban, életükben egyaránt. 

karrierjében is valami értelmet keres elsósorban. Szóval azt hiszem, hogy aki egy gondolkodó, komolyan gondolkodó ember komolyan veszi azt, hogy az életének az egyik legfontosabb része a munkája hogyan teljen el, és azt mivel töltse az igazából értelmet keres az életének. Én is kerestem ezt az értelmet, ha nem is marha tudatosan fiatalkoromban, de mondjuk $O K$ akkor fogalmazzunk úgy, hogy velem ilyen élet értelmének a megtalúćs vagy abban történó váltás történt. (Sára)

A 2. ábrán a minta narratívájának fó ívét jelenítjük meg, összefoglalva a váltási folyamat legfóbb állomásait, szakaszait és ezek jellemzőit.

\section{Átlépés jellegú karrierváltások}

Az átlépés jellegú karrierváltások az elhagyás és a keresés jellegú váltási folyamattól több szempontból eltérő jellemzốket mutatnak. Minden tizedik karrierváltási folyamatban az egyik karrierállomásról a másikra való attépés szinte összecsúszik, kiindulópontja egy új le hebesïltek kényszerhelyzetekkel, nem érlelődött bennïk kritikus elégedetlenség, elhagyási szándék, sem valamilyen cél, vágy elérésének terve. A váltásokról szóló szövegek mindössze 2-3 mondatban hangzanak el, tudósítás jelleggel, amelyben a körülmények és a helyzetet tényszerúen leíró mérlegelt tényezók, valamint

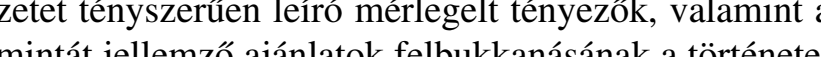
"nan kapnak helyet. A váltás így egy könnyed, ,megtörtén" eseményként kerül elmesélésre, ami alapvetően eltér az elhagyásról szóló részletes magyarázatokat tartalmazó dramatizált történetektól, és az új alternatíva kialakuásáról szóló, érzelmekkel, dilemmákkal, önismereti tartalommal tarkított karrierlépésektól is.

A minta jellemzését itt is további csoportok, tipikus jellemzók bemutatásával kezdjük. A kérdések, amelyekre választ keresünk: Milyen helyzetekból alakulnak ki ezek a váltások? Miért eredményeznek karrierváltást? Miért túnnnek könnyednek?

\section{Csábitás}

Az átlépés jellegú váltások felében az alanyok sen az elhagyás gondolatáról, sem az aktuális karrierállomással kapcsolatos elégedetlenségrốl nem beszélnek, mindössze egy új lehetóség felbukkanásáról szólnak

A keresés jellegú narratíva íve

Váltás 'valami felé'

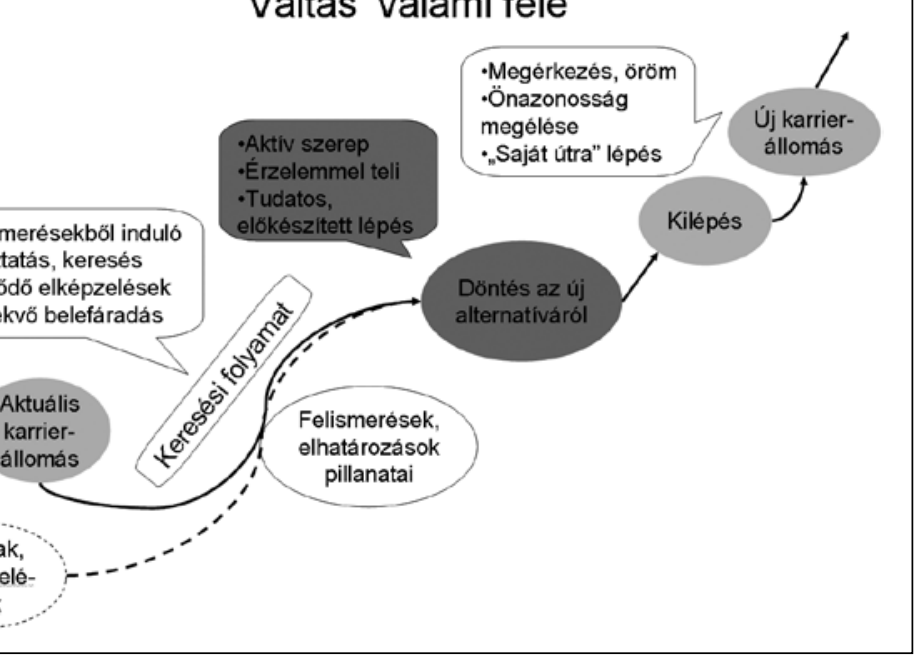

váltási történetek. A lehetőségek mind ajánlatok, amelyek a váltók kapcsolatrendszerén vagy fejvadászon keresztïl érkeznek, és amelyeket az alanyok nagyobb dilemmák nélkïl elfogadnak Az új alternativa jellemzôn megfoglmán an vonzó jellegét, de .

\section{És hát kaptam egy megkeresést, igazából a váltás} is teljesen adta magát, egy fejvadász cégen keresztül, az X céghez, mert hogy akkor a telekommunikációban kerestek informatikus szakembereket, hát micsoda klassz dolog, végre akkor multi meg utazás, ez igy eljesen rendben volt. (Judit)

És elvállaltam, ezt csináltam 3 évig, és tavaly nyáron megint csak megkerestek X városból. Miközben léptem volna elöre a ranglétrán a multinál, megkerestek ezzel az $x$ városi történettel, és azt mondtam, hogy 47 évesen nem tudok ellenállni a hívásnak, és feladtam a kényelmes multikarriert, pénzt, paripát, fegyvert és beleléptem ebbe a kicsit zürösebb történetbe. (Mátyás)

Élveztem a tanítást. Jó volt. Jó volt, a gyerekek is jók voltak, a kollégák is. Aztán jött a telefon igen. És mit tudom én vagy háromszoros-négyszeres fizetésért csábitottak el. Meg engem ószintén érdekelt ez a dolog. (Géza)

Ezek a váltások többségében szektor- vagy munkaerô-piaci státusváltást eredményeznek, de néhány esetben szakterületváltás is történik. A váltások szinte véletlenszerúek, az új lehetôség kialakulásakor az alanyok gyors döntést hoznak, ami különösebb mérlegelésre, magyarázatra nem szorul. Vélhetóen az aktuális és az új lehetớség összevetése kapcsán egyértelmú választ találtak, melyet azonban nem mindig fejtenek ki. Legtöbben a kihívást, az új, érdekes feladatot, illetve jobb feltételeket és lehetőségeket említik (pl. magasab fizetés, multiba bekerülés), és ez önmagában indoka a váltásoknak. Úgy tű́nik, az aktuális munkájukhoz és munkahelyükhöz kevéssé kötôdnek, így az elhagyást nem kíséri érzelmi teher. A karrierváltás tehát az új lehetőség kialakulásával, az ajánlatok beérkezésével indul, és szinte ezzel egy idóben születik meg a döntés ezek elfogadásánól és az elhagyásról, valamint a kilépés

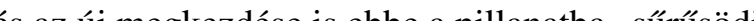

\section{Nyitás}

A csábítástól ezek a váltások abban különböznek, hogy az alanyok utalnak arra, hogy az elhagyás, továbblépés gondolata már megfordult bennük az új lehetôség kialakulását megelőzzóen. Jellemzóen unalomról, belefáradásról, a kihívás elvesztéséról, valamilyen ú érdeklő́dés megjelenéséról tesznek említést, ezzel indokolják, hogy nyitottá váltak a továbblépésre. Azo ban ezek az élményeik nem mélyülnek el, nem indít el bennük elbizonytalanodó, önismereti jellegú folyamatot. Ennek oka lehet az is, hogy mielótt még megoldás kellene keresniük, az ajánlatokban lehetôséget látnak a továbblépésre, valamint vélhetốn kevéssé kötődnek az aktuális karrierállomásukhoz, így érzelmi nehézségekkel sem szembesülnek.

Ugye az elején odahívtak, hogy építsem fel és csináljam meg. Felépitettem megcsináltam siker és '98-ban kezdtem el és 2002 vagy 2001-ben al mondtam, hogy vagy 2002 elején igen, hogy én még egy évet lehizok itt a 2002 es lesz az uolos cin mes utén valami más keresek, mert nincs ur nek

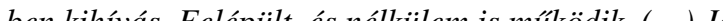
volt mit csińlni de összességében feleslegesmek ́reztem magamat. És akkor jött egy megkeresés...(József)

Három év után úgy éreztem viszont, hogy egyszerüen nem, nem tudok igazan megmozgatni elegendo erót hozzá, hogy korai az erófeszités. Ráadásul akkor hivtak haza, és akkor XY, az akkori vezérigazgatója az XY banknak már két ajánlatot tett nekem, a har madiknak nem tudtam ellenállni, és akkor az XY bank által létrehozott XY Rt.-nek lettem az alapitó vezérigazgatója. (Mátyás)

Ahogy az idézetekból is látható, az elhagyás gondolatának kialakulása és a válás kôzôtt rôvid idô telik és az esetek többségében egy beérkező ajănlattal váli aktuálissá a karrierváltás, amelyet az alanyok elfogadnak. Ok mind nagy szervezetek (állami vagy multi) felsố vezetôi, és mind férfiak, ami egyrészt a felmeru- lő elégedetlenségeket és a kapcsolatrendszer múködését is magyarázza. A vezetốk esetében nem meglepó, csak három alany „mozgatja be” ezt aktívan az új lehetóség kialakulása érdekében.

Volt egy kicsit, hogy jó lenne továbblépni valamit, még valamit tanulni egy kicsit még a gyakorlatiasabb kutatáshoz, tehát ebból a szempontból az XY-nak a mozgassa, az ugy egyreszt meginditotta bennem azt, hogy hú, hát miért ne lehetne ezt is kipróbálni. (...) Es akkor mondtam neki, hogy szivesen atmennék hozzád, ó pedig azt mondta, hogy örömmel fogad. (József)

Amikor az informálisan elkezdett terjedni, meg nyilvános helyeken is bejelentettem az X bankban, 2006 elején, hogy akármi fog történni. 2007. március után nem szeretnék ott dolgozni, hanem valami mást szeretnék csinálni. Tehát amikor csináltam egy ilven nyilvános elkötelezettséget, akkor utána ez igy terjedt a városban, akkor elég sok állásajánlatot kaptam, és hál istennek senki nem akart elemzóként foglalkoztatni, holott lett volna ilyen, de én biztosan ilyet nem akartam, és elég sok vezetóí állással kináltak meg, akkor több is volt, elsó számú vezetói allás. A különbözóo megfontolások alapján végül is amellett döntöttem, hogy az X bankhoz jö̀ök elsó́ számú vezetônek. (Ákos)

Ezek a váltások tehát a továbblépés gondolatával indulnak, de az ajánlatok felmerülésével válnak valóságossá, hiszen az alanyok az elhagyásról szóló döntést többségében akkor hozzák meg, amikor már az új lehetőség kialakult. A váltás folyamata gördülékeny, az új lehetôség a vonzó, és a régiből való kilépés kapcsán sem beszélnek nehézségekrôl, dilemmákról. A váltásban fontos tényezóket, az elhagyást magyarázó tolóerôket mintha az új alternatíva egyértelmúen kielégítené, azonban ezek az aktuális karrierállomásból származó hiányérzetekként kerülnek megfogalmazásra.

Az átlépés jellegú váltások mintáit a kiinduló helyzet megragadasa menten a 4. táblázatban foglajuk ossze.

\section{Az átlépés tudósító jellegü narrativája}

A teaház után, illetve utolsó évben már párhuzamosan, már az is egyfajta karrierváltás volt valahol, mert a kisvállalkozói létból kikerülttem, és a Mindentudás Egyetemének lettem a projektvezetóje, ami, Oegint egy gyönyörü feladat volt. (Márton)-

Odakerültem az épitóiparba, hamar láttam hogy en vilagom, utána mentem el a sportegyesülethez gazdasági vezetônek a per után, a hütlen kezelés után. (Péter)

\section{VEZETÉSTUDOMÁNY}


Az átlépés jelleguí váltások összefoglalása

\begin{tabular}{|c|c|c|c|}
\hline Alminta & Kiinduló helyzet & Miért határváltás? & Miért könnyed? \\
\hline Csábítás & $\begin{array}{l}\text { Elégedettek az aktuális } \\
\text { karrierállomásukkal. Váratlanul } \\
\text { bukkan fel az új lehetớség. }\end{array}$ & $\begin{array}{l}\text { Az ajánlatok többségében más } \\
\text { szektorból érkeznek, és esetenként új } \\
\text { szakmai területról. }\end{array}$ & $\begin{array}{l}\text { Nincs különösebb okuk a továbblépésre, de } \\
\text { nincs kötódésük sem, vonzóbbnak ítélik az } \\
\text { új lehetôséget. }\end{array}$ \\
\hline Nyitás & $\begin{array}{l}\text { Megfogalmazódó elégedetlenség az } \\
\text { új lehetớség megjelenése elótt. }\end{array}$ & $\begin{array}{l}\text { Az új lehetốségek, ajánlatok más } \\
\text { szektorból éreznek, néhány esetben } \\
\text { szakmavátás is történik. }\end{array}$ & $\begin{array}{l}\text { Megfogalmazódik bennük a továbblépés } \\
\text { szándéka, de mielótt még döntenének, már } \\
\text { elóáll az új, vonzó lehetơóse. }\end{array}$ \\
\hline
\end{tabular}

A mintának egyedi jellemzóje, hogy a karriervált sokról szóló szövegek feltủnóen rövidek és az alanyok úgy fogalmaznak, mint ahogy egy tudósító beszámol a nap tényszerú eseményeiról. Ez értelmezhetố úgy, hogy nem kiemelt események ezek a karrierváltók életében. Pontosabban: a váltás folyamata nem fontos, sokkal inPább annok megtörténte az érdekes, azaz, interjúalany ennek a lépésnek a folyamatát nem tartotta fontosnak a 'mondanivaló' szempontiából, aminek több ontosnak

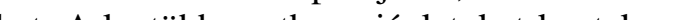
het. A legk nuilon ok maguk kulosossebb lépéseket nem tettek, igy se megelôzó dilemmákrơl, sem fontos történetekrỏl ne tudnak beszámolni. Ugyanakkor az is lehetséges, hogy az alanyok más váltásaikat (az interjúalanyok többsegének 3-4 karrierváltása volt) kiemeltebb eseménynek tartották, így ezeket a váltásokat csak „,megemlítik”.

$\mathrm{Az}$ érzelemmentesség is jellemzi ezeket a narratívákat, amiből arra következtethetünk, hogy az aktuális karrierállomáshoz nem volt különösebb kötốdésük, az elhagyás nem jelentett lelki terhet, mint ahogy az ajánlat elfogadása sem. Egyfajta evidenciát sugall a tudósítás: az események ebben a sorrendben történtek, hiszen hogyan is sító jellegbe váltási folyamat így egy idốpontba sưrúsödik.

Ugyanakkor a nyitásban lévốk közös jellemzője, hogy a váltásról való beszámolóba egy elôzetes magyarázatot fogalmaznak meg, amivel érthetóbbé és még evidensebbé teszik a továbblépést. Ez a motívum értelmezhetố utólagos magyarázatként is, azaz az alany már visszatekintve teszi önmaga és a hallgató számára is érthetốbbé, elfogadhatóbbá a döntését.

A váltási folyamatról szóló beszámolókban feltún a passzív szerkezet, vannak olyan megfogalmazások, amelyeknek a tartalma és a megfogalmazás módja is passzív.

Minden esetben, itt is az volt, hogy engem kerestek meg. S akkor ott az elnök választott ki maga mellé, nemzetközi tum ís elónak, dolgozturk egyidt. (Mátyás)
Hirtelen, tehát tényleg egy hétvégén történt a dö belga vezérigazgatóval, aki itt az $X$ multicégnek volt 政 szóvivójévé. (János)

A passzivitást tükröző kifejezések lényege, hogy valaki másra vonatkoznak az igék, valaki más a cselekvő. Ez azért is érdekes, mert - bár az ajánlatok alapjan történố váltásoknál az egyén értelmezhetố passzív szereplônek - az ajánlatok mögött feltételezhetôen van valamilyen teljesítmény. Az olvasatok egyik lehetósége, hogy az alanyok az aktív szerepet ,szigonu

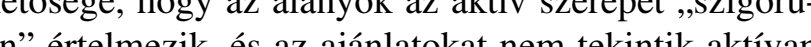

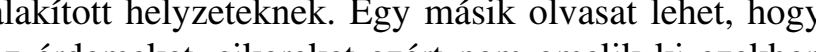
az érdemeket, sikereket azér nem enelik ki ezekben a esetekben, mert egy ajta szencen, veletlennek artják. Ez jelentheti a bizonytalanság kifejezódését, amit a történet elmesélésével újra átélnek és megjeenítenek; azaz az akkori helyzetben az új alternatíva kialakulását külső tényezốk összejátszásának, és nem saját kontroll alatt tartott eseménynek élték meg. Egy következő olvasat, hogy az ajánlatok kapcsán „rábízzák a hallgatóra" annak eldöntését, vajon mit jelent egy ennem az új lehetóségért? Talán azt, hogy sikeres, tehetséges, elismert vagyok. Azonban a passzív szerkezet pont az ellenkezójét sugallj. Ez a gond szenezet ponan értelmezést is felvet, hogy az alanyou itt a se rescé resseg nyezik maguka", sót tompitják a megfogalmazásukkal karrieralternativa kialakíasaban „,alojaban” mekkora proaktivitása van az egyénnek. Ez utóbbi értelmezés felveti a kérdést, hogy vajon ma nem „illik” sikeresnek lenni, vagy csak nem illik erról beszélni? Vajon a mai magyar társadalom szereti vagy nem szereti a sikeres embereket? Ezeket a kérdéseket természetesen itt nem tudjuk megválaszolni, de alább visszatérünk a siker lehetséges értelmezéseire. tés, egy következó váltásnál, ahol megismerkedtem, gyakorlatilag egy baráti tolmácsolás alkalmával, egy " ét le the es az ajo ilyen történés. Mit jelenthet az, ha egy lépést sem kell sikerességüket, függetlenúl attól, hogy a váltás során a
A 3. ábra a minta narratíváiának fő ívét jeleníti meg a váltási folyamat állomásain keresztuil.

Az átlépés jellegú narratíva íve

Váltás 'csak úgy'

Konklúzió

A bemutatott karrierváltási mintákon keresztül a vátási folyamat megragadására tettünk kísérletet, leírva és magyarázva a váltási történetek kiindulópontjait, fô dramaturgiáit, meghatározó szakaszait. Az elemzés és csoportosítás egyaránt ötvözi a narratív és a tartalmi elemeket, amelyekben a feltúnó jellemzókön keresztü a különbségek megragadására és értelmezésére törekedérdései menté minták jellemzóit, ami az elemzésre alapot ac. kiindulopontja adja, ennek kovvetkezményeként pedig
5. táblázatból is látszik, hogy a minták megragadásában a legfobb hangsúlybeli különbséget a vált a váltás szakaszai, azok fố dilemmái és megélése is el-

térô. Az elhagyás jellegú váltások az egyének élettörténeteinek, sốt identitásfejlődésének is a fordulópontjait jelentik. Láthatóan a karrier önmenedzselésének elvállalása jelentős eltoló erók miatt következik be: a multik által kínált karrier, a hivatás megtalálása révén elképzelt, biztosnak túnő útvonalak, vagy az ugyancsak hosszú távra tervezett, de sikertelen karrierállomások (vállalkozások) esetében is. Így nehéz, hosszadalmas és traumatikus döntéshozatali folyamatok eredményeképp érkeznek a váltók ahhoz a fordulóponthoz, amelyben a hagyományos karrierfelfogást tükröző pályájukat ér jüket és gyakran teljes életvitelüket.

A keresés jellegú váltások kiindulópontját az önirányitás felvállalásának folyamata adja, amelyben a megfogalmazott dilemmák, célok és az új alternatíva kialakításának szándéka, módja mind húzóerókként jelennek meg. Az identitásmunka már korábbról indul, ennek következményének tekinthetố a kereső karrierváltás, amely ugyancsak fordulópont a váltók életében, mert eredményében a célok, vágyak beteljesülését hozza. Azonban az alanyok karrierútjából az látszik, hogy ez a lépés korántsem egyszerú, hiszen a karrierdöntések mögött meghúzódó elakadások, valamint a célok tudatosítása és megértése mélyen megélt több váltáson keresziil elhúzódó, számos kudarceal is tarkított folyamat.

Az átlépés jellegú minta legszembetúnóbb eleme, ogy az előzố mintáknál megjelenő fordulópont jelleg, dentitásváltozási folyamat, vagy a váltás érzelmi megése nem jelenik meg, így az eltérések mentén az elôzó két minta kiegészítését adja. Hagyományos karrierfelfo-

A minták jellemzó

\begin{tabular}{|c|c|c|c|}
\hline & Elhagyás jelleg & Keresés jelleg & Átlépés jelleg \\
\hline Kiindulópont & $\begin{array}{l}\text { Munkahelyi/szervezeti kontextusban } \\
\text { felmerüló, abból kiinduló elakadás/ } \\
\text { kényszerhelyzet }\end{array}$ & $\begin{array}{l}\text { A személyes célok, vágyak, } \\
\text { elképzelések felerősödése }\end{array}$ & Új lehetốség felbukkanása \\
\hline $\begin{array}{l}\text { Mozgatórugók, } \\
\text { mérlegelt tényezók }\end{array}$ & \begin{tabular}{|l} 
Eltoló erók: hiányérzetek, elakadások \\
- biztonság, egzisztencia \\
- értéküttoózzés, munka-magánélet, \\
identitás dilemmák
\end{tabular} & \begin{tabular}{|l} 
Húzóerók: vágyak, célok \\
- önazonosság \\
- kongruencia \\
- önmegvalósítás \\
\end{tabular} & \begin{tabular}{|l} 
Húzóerók: új alternatíva \\
- kihívás \\
- elóbbre jutás \\
- anyagiak \\
\end{tabular} \\
\hline Szakaszok & $\begin{array}{l}\text { 1. Szembesülés az elakadással } \\
\text { 2. Elhagyás megérlelése és döntés } \\
\text { 3. Megoldáskeresés (gyakran } \\
\text { karrierszünetben) }\end{array}$ & $\begin{array}{l}\text { 1. Célok, vágyak tudatosítása } \\
\text { 2. Az új lehetóség kialakítása } \\
\text { 3. Elhagyás és az új alternatíva } \\
\text { megkezdése }\end{array}$ & $\begin{array}{l}\text { 1. Új lehetóóség felbukkanása } \\
\text { 2. Mérlegelés és döntés a } \\
\text { továbblépésról }\end{array}$ \\
\hline A megoldás & $\begin{array}{l}\text { Válasz a hiányérzetekre és a váltási } \\
\text { folyamatban megfogalmazott dilemmákra }\end{array}$ & $\begin{array}{l}\text { A vágyott elképzelések, az } \\
\text { illeszkedés elérése }\end{array}$ & $\begin{array}{l}\text { Elốrelépés a szakmai pályán, } \\
\text { jobb feltételek }\end{array}$ \\
\hline $\begin{array}{l}\text { Megélés, } \\
\text { fó dramaturgia } \\
\text { (narratív elem) }\end{array}$ & $\begin{array}{l}\text { „Váltás el valamitól'”: elhagyás, ami nehéz, } \\
\text { traumatikus, érzelmekkel teli. }\end{array}$ & $\begin{array}{l}\text { „Váltás valami felé”: az új } \\
\text { alternatíva magyarázata, a lépés } \\
\text { megélése érzelmekkel teli }\end{array}$ & $\begin{array}{l}\text { „Váltás csak úgy” könnyed, } \\
\text { röviden és evidenciaként } \\
\text { megjelenó }\end{array}$ \\
\hline
\end{tabular}

\section{VEZETÉSTUDOMÁNY}


gásról itt bizonyára nem beszélhetünk, legalábbis nem kerül felszínre olyan tartalom, ami a karrier tradicionális felfogását tükrözné, sôt, a váltás természetesne magától értetốdônek tưnik. Objektív szempontból teh karrierváltás történik, azonban a karrier újszerú, egyén jellemzó elemeivel ez a minta nem, vagy nagyon nehezen magyarázható. A minták összegzó jellemzóiben is vannak eltérések az elmélet által hangsúlyozottakhoz képest, emellett azok sokszínúsége az almintákon keresztül is kibontakozik. Érdemes külön is megvizsgánunk az újszerú karriert léró jellemzóket, amelyekhez nunk aź úk alapján alakítjuk ki viszonyulásunk a minták alapján ank gondolást jelentố kérdéseket, dilemmákat is.

\section{Adaptáció és önirányítás}

A szakirodalom érvelése szerint az újszerú karrie megjelenése a gazdasági környezet és szervezetek változására adott válasz, mintegy a kor követelménye. H a szervezetek határok nélkülivé válnak, és nem képesek többé hosszú távú foglalkoztatást kínálni, akkor a munkavállalók felé is megjelenik az elvárás, hogy képesek legyenek határokon át mozogni (Mirvis - Hall, 1994). Amennyiben elfogadjuk a formaváltó karrier magyarázatát és elófeltételeit, akkor a környezethez való sikeres adaptáció feltétele az önirányítás, ami belsố irányított-

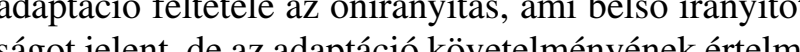

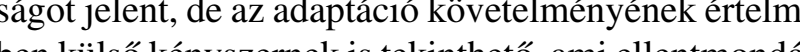
ben külsô kényszennek is tekôt

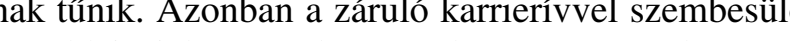
jó példái a jelenségnek, számukra a ,nem ettól a cégtó es nem is ebbôl a szektorból, karrierpályáról megyek nyugdíjba" realitása magatartásváltozást követel meg. Az elhagyás jellegú váltásoknál kirajzolódik tehát egy olyan folyamat, amely az adaptáció kényszerével, kényszerú önismeret nehézségeivel indul. A felelốsségvállalás, a karrier önirányítása úgy is értelmezhetố, hogy mindezt azért vállalják, mert a szervezet már ne vállalja fel helyettük

Ezzel szemben a keresés jellegú váltásoknál az önirányítási folyamatot hangsúlyoztuk, ugyanakkor itt em tekinthetiink el a környezeti hat́soktól. Búr ezek a

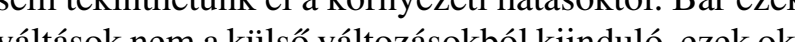
valícok kialakuló reakciokrôl szónak, mégis a történetekben is szerepet játszanak egyfajta „, Oó erókén " kulônböz szervezeti behatások. Itt ezek azonban kevésbé kényszer jellegúek, inkább egyfajta „apropót” jelentenek régóta érlelt elhatározások megvalósításához.

A formaváltó elméletben szereplő pszichológiai költségek ugyancsak mindkét mintában megjelennek: míg az elhagyásoknál az önirányítás felvállalása, az ezzel való szembesülés jelent nehézséget, törést, addig a keresés jellegú váltásokban maga az önirányítás folyamata, az önismerettel járó felismerések, az ebből következó elakadások jelentenek terhet, valamint a tudatosság és a felelôsségvállalás révén kell viselniük döntéseik következményeit. A pszichológiai terheket az elhagyás váratlansága és aztán a megoldások megtalálásának folyamata is tovább árnyalja, ók az adaptációs kompetenciára építve indulnak el, míg a keresés az önismereti kompetencia meglétére épül.

Az átlépés jellegú váltásokat nehéz e dimenziók mentén elhelyeznünk, bár az ajánlatok, lehetőségek mentén való továbblépés értelmezhetó egyfajta reakcióként, amely mentes az adaptáció pszichológiai techeitól. Ebbe a mín az

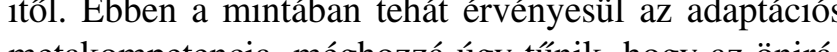
metakompetencia, méghozza úgy tûnik, hogy az önirányitás nehézségei nélkul. Tekinthetjuk vajon ezt a mintát az újszerü karrier egy sikeres, könnyed formájának? Vagy az ajânlatok elfogadása nem tekinthetó önirányításnak? A kérdések megválaszolásához érdemes megvizsgálni az adaptációhoz és önirányításhoz szorosan kapcsolódô témákat, mint a felelősségvállalást, tudatosságot, sodródást. Jelen cikkben ezekre nem terüunk ki, de tanulságos elemzési szempontokat adhatnak a karrierváltások kiindulópontjainak megértéséhez. Mindemellett megállapítható, hogy a karrierváltások mindenképpen a környezettel való kapcsolatban születnek, azonban a behatások feldolgozása az adott reakció és az önirányít́s jellege

\section{Önismeret és identitásváltozás}

Az önirányításhoz szorosan kapcsolódó, az elméletekben az újszerú karriert megjelenító egyéni jellemzó az önismeret és identitásmunka. A formaváltó karrier elméletek magyarázati logikáját a karrierváltásokra a következóképpen fordíthatjuk le: az önirányító egyén az önismereti, tanulási folyamatainak eredményeképp a folyamatosan fejlódô, változó céljaihoz, motivációihoz igazítja karrierjét, egyre nagyobb koherenciát teremtve a különböző, életben betöltött szerepei között. Ez a logikai lánc a keresés jellegú váltásoknál a szövegek tartalmából is kirajzolódott hiszen az alanyok maguk

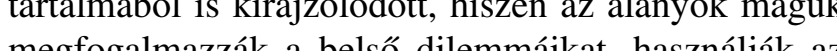
öno tájuk kÖzOri kongunkajuk kozố kongruencia keresését explicitté teszik Az identitásvalátozás tehát ezekben a váltásokban jól megragadható, bár az elmélettő́l eltérően ezek forrása, eredete gyakran éppen a szullôktôl, mentoroktól jövô, kijelöltnek vélt utakkal való megküzdés.

Hasonlóan intenzív küzdelem húzódik meg az elhagyás jellegú váltási folyamatokban felmerüló dilemmák mögött is, de mint már arra utaltunk, eltérô kiindulópontból, az önismeret kényszerét is felvető magyarázatokból válik érthetốbbé a váltási folyamat. Ezekben a váltásokban a társadalom által kijelöltnek vélt szerepe és karrierértelmezések, -útvonalak kerülnek a konfliktusok középpontjába. A „,deal” felmondásból kiindul váltásoknál a „deal” felrúgása mögött a különbözô szerepek és életszférák közötti feszültség is megtalálható amely eredményeképp döntést hoznak az alanyok eze összeegyeztetésének módjáról. Van, aki nagyobb illeszkedést, önazonosabb múködést valósít meg, van, aki a feszültséget úgy oldja meg, hogy prioritásait átrendezi, de például jellemzően a nói vezetốk munka-magánéleti szerepeinek fragmentációja megmarad: mikor az anyaszág mellett döntenek, egy idóre egyfókuszúvá (csak „magán én”) válik az életük, majd a munkába vissza„magán én") válik az életük, majd a munkáb

A hivatás elhagyása kapcsán megfigyelhetố egy erós szakmai identitás, ami megtörik a váltással, és végere ményében erôteljesebb feszültséget eredményez a ,,személyes én” és a „munkahelyi én” között. Az adaptác kényszere és az önmegvalósítás összeütközése látszik itt, amely a formaváltó elmélet két központi eleme. Ezekben a váltásokban az adaptáció válik erósebbe, példa erre, amikor a hivatás- és küldetéstudat, valamin az egzisztenciális szükségletek összeegyeztethetetlenné válnak. Az anyagiak, a pénz szerepe és hatása a ka rierváltásokra egy külön elemzési szempont is lehet, itt - kapcsán utalunk a téma érdekességeire.

Mint látható, az elmélet az önismeret szerepét azza is indokolja, hogy a különböző, életben betöltött szerepek közötti konfliktus fragmentációhoz, azaz egyfajt hasításhoz vezethet a külonbooző „ének” között. A ka rierváltásokat tekinthetjük válaszként ezekre a konfliktusokra, vagy éppen az adott karrierciklusban változo célok és motivációk eredményeképp erôsödnek fel.

Az átlépés jellegú váltásoknál viszont nem tudunk következtetni hasonló konfliktusokra vagy küzdelemre, ott ezek a dilemmák nem merülnek fel. Vajon az önismeret vagy önirányítás dilemmáitól mentes határátlépések mögött egyfajta koherencia húzódik meg, vagy csak objektív váltás történik szubjektív karrierváltá nélkül?

Mint azt láthatjuk, az újszerú karrier egyik központ fogalma az önismeret, amely alatt az identitásmunka pszichológiai siker, önmegvalósitás fogalmai is szerepelnek. Az elméletek szintúgy kiemelik ennek jelentőségét, mint a szakkönyvek, a különbözó képzése továbbá a HR és a tanácsadói, fejlesztôi szakma. Így az sem meglepő, ha az interjúalanyok "képzettek” abba a tekintetben, hogyan mutassák meg „,belső útjukat”, hogyan tegyék láthatóvá önismereti folyamataikat. Az önismeretról való beszéd egyfajta társadalmi elvárásként is értelmezhetô, hiszen a „képzett” interjúalany szövegeiben szerepelni fog erre utaló megfogalmazás, mint ahogy például a pszichológiával foglalkozó alayaink tơrténeteiben ez szembetúnó. $\mathrm{E}$ kritikai olvasattal nem elsősorban ezek valódi tartalmát kérdójelezzük meg, hanem inkább arra a tendenciára hívjuk fel a figyelmet, hogy a pszichológiai siker értelmezése és az ehhez kapcsolódó belső folyamatokról való gondolkodás és beszéd egyre inkább megjelenik az egyének karrierhez füződó viszonyában.

\section{Pszichológiai szerzódés}

A tanulmány elején már utaltunk arra, hogy a tranzakcionális szerződést az újszerú karrier alapjának tekinteni nem szerencsés, legfeljebb egy kibővített értelmezési keretben. Kutatási eredményeink is azt támasztják alá, hogy a szervezettel kötött üzletben az ellentételezés nem csupán anyagi lehet, hanem a tanulási és fejlődési lehetôség, a kihívó munka is a szerződés részét képezheti.

Azt viszont fontos kiemelni, hogy általában a nagy szervezetekhez, foleg a multikhoz való viszony jellege az interjúalanyaink többségénél tranzakcionális jellegú, és ritkán fonódik össze hivatástudattal, küldetéstudattal. Az ügyalapú elköteleződések színtere általában a civil szféra, ahol viszont nem érvényesiil a

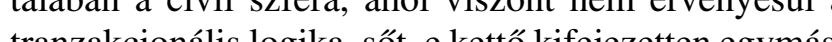

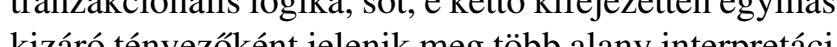

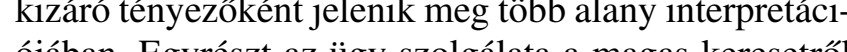
ojában. Egyreszt az ungy szolgálata a magas keresetró feć vań vít́s is magaval vonja, mástészt a hivatás felé való váltásokat jellemzóen már biztos anyagi háttérrel rendelkezve lépték meg az alanyok. Az esetek többségében így válik lehetôvé, hogy a hivatásnak való élet és a pénz utáni hajsza ne kerüljön feszültségbe. Ebben az értelemben teljesülhet az a formaváltó irodalomban említett ideáltipikus eset, amikor a munkavállaló számára a fizetés csupán „ajándék".

A pszichológiai szerződés nem változott olyan mértékben, mint azt az elmélet feltételezte, nem teljesül a szakirodalom azon állítása, hogy a megváltozott pszichológiai szerzôdés szerint a munkavállalóknak már nem fontos a biztonság (Arthur, 1994; Mirvis - Hall, 1994) A biz biztonság vágya az anyagi függetlenś́g vágya uganúgy jelen van. Ennek jó példái a hivatást vaga ugyanerváltási döntések, melyeket szinte minden eyotbent egiszi dontesek, melyeket szinte minden esetben az egziszencialis szenpontok notivának. Felfigyeltünk arra, hogy az általunk vizsgált karrierváltásoknál érvényesül egyfajta sorrendiség: a karrier korai szakaszában jelentősebb mértékben befolyásolják a karrierdöntéseket az anyagi szempontok, mint késóbb, amikor már sikerült kiépíteni a megfelelố egzisztenciális háttere és az önmegvalósitás, ügy szolgálata kerülhet elôtérbe. 
Ennek a sorrendnek a felborítása látható módon nem múködik: ha valaki olyan gyermekkori álomhivatás választ pályakezdôként, amely nem jól fizetô szakm jelent (pl. tanár, katona), az néhány éven belül anyagi problémák miatt feladni kénszerül azt. (Itt természetesen meg kell jegyezni, hogy a mintánk torzított, hisz csak karrierváltókat vizsgáltunk.)

A tranzakcionális szerzódéstípus és az intrinsic motivációk által vezérelt egyén képe tehát több ponton is dilemmákat vet fel. A pszichológiai siker és a belső motivációk párhuzamba állítása, szemben a materiális (köztiik az anyagi) szempontokkal, téves következtetésok túk az anyagi) szempontokkal, téves kovetkeztetések es leegyszerüsitổ magyarázatokra ad lehetőséget. A mi ták bemutatásával megkíséreltük ezeket a szempontok összefúggésében bennta a váltások mozgatórugóinál kiemelt motivációk melle

\section{Mit jelent az újszerü karrier?}

A választ az objektív és szubjektív perspektívák valamint a szúkebb, illetve tágabb karrierdefiníciók értelmezésén keresztül adjuk meg. Az elméleti részben már utaltunk arra, hogy határváltó és a formaváltó elméletek magyarázati logikájában keverednek nézôpontok. Kutatásunk során megkíséreltïk ezek tisztán tartani és a perspektívákat egymásra épéten.

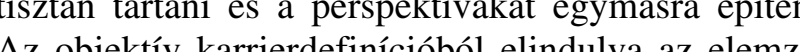
Az objektiv kema elemzes során arra a kérdesre kesestuk a választ, hogy milye folyamat vezet hatroflepenat elsósorban már szubjektív perspektívából adtuk meg: az egyénben zajló változásokat összekapcsoltuk a váltás folyamattal és annak következményével, a határátlepéssel. A magyarázatokat tehát az egyénból kiindulva alkottuk meg, figyelembe véve azonban olyan környezeti, a váltás tágabb kontextusát befolyásoló szempontokat is, amelyek az egyéntól függetlennek tekinthetók (például társadalmi változások). E tényezók és a karrierváltás között viszont nem hangsúlyozunk ok-okozati kapcsolatot, egyrészt azért, mert nem vizsgáltunk „nem váltókat”, másrészt azért, mert szubjektív nézô"nontból, az a dottś́gnak tekinthetó kiüső változások és lehetśges öszzefüggé a lehetsếges összefüggések is csak az egyén interpret cióján keresztül értelmeződnek azzá.

A határváltó karrier elmélete keretet ad a karrie viselkedés szervezeti szempontú megragadásához, es felhívja a figyelmet a hagyományosan határokna tekintett keretek elmozdulására. A határok átlépés egyben karrierváltást is jelent ebben a keretben. Ilyen módon a határváltó formák megfigyelése és megragadása a karrierdefiníciókra is reflektál: az objektív nézőpontból látható karriermintázatok meghatározásában a karrierértelmezés tágulása is megjelenik.
A kutatásunkban definiált (az elméletben is szereplô) határváltó formákba például megjelenítettük a munka es magánélet szerepeinek átrendezését és újradefiniálását, amely mögött felfedezhető egy tágabb értelmezés: a karrier nem csak a szakmai életpályán betöltött pozíciók sorozata. Elsốsorban azonban a „határok tágulása" révén tér el a hagyományos karrierfelfogástól: azaz a karrier határon átívelő szakmai és magánéleti szerepek sorozata.

A formaváltó elméletek inkább karrierciklusokról beszélnek, amelyek lerövidülését az egyén önmenedzselt karnekoncepiójával magyázźn Ez ugyan-

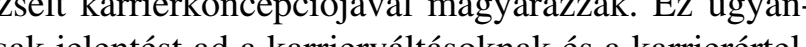
encluncén aj karrierciklusba lép, azaz új tanulási görbét kezd meg és visz el a kiválóság szakaszaig. A mozgatórugó a két hurkos tanulás révên elérni kívant célok és szerepek integrációjának igénye. A karrierciklus ilyen módon nem feltétlenül köthető össze objektív karrierváltással, bár ezt az elmélet nem teszi egyértelmúvé. A tágabb értelmezés viszont megjelenik, hiszen az „integrált én” és az „életstílus koncepciô” feltúnő hasonlóságokat mutat, ami a hagyományos felfogástól jelentôsen eltér.

A kutatás alapján azt állítjuk, hogy egy objektív pers-

pektívából újszerúnek mutatkozó karrier nem feltétlenui jár együtt a szubjektív perspektívából újszeríként tár-

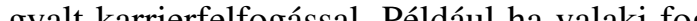

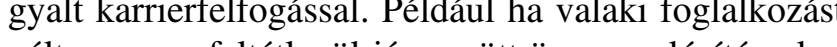
teles en fibon

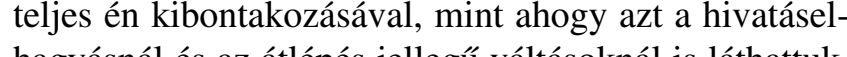
hagyásnál és az átlépés jellegú váltásoknál is láthattuk. Ugyanakkor az álitás forditva is igaz lehet. a szubjektív perspektívából az egyén interpretációjában megjelenố változás, váltás (új tanulási görbe) nem jelent objektíve megfigyelhetố karrierváltást. Mivel a kutatásban az objektiv karrierváltási mintázatokbool indultunk el, így az utóbbi jelenséget vizsgáló elemzést nem végeztünk, ugyanakkor számos szövegrészletben az alanyok explicit megfogalmaztak olyan - szubjektív jellemzókkel leírható - váltásokat, amelyeket a határváltó kategóriáink nem kezeltek (például meghatározó iskolaváltás). A szakirodalom (tér ki erre a dilemmín, holots (pelott a nye leter az is hogy az elemés kizánye lehet az is, hogy az elemzés kizárólag az egyéni interpretációból indul ki: karrierváltás az a folyamat, amelyben az egyén jelentốs tanulási folyamatról, a megésében ujj karrierciklus megkezdéséról számol be.

A szubjektív nézőpontot felerósítve az alanyok által használatos karrierdefiníció valahol a fenti két pólus között helyezkedik el. Karrier alatt a szakmai életpálya történéseit, az annak során betöltött szerepeket értik hisz erról beszélnek ${ }^{5}$ : az egyik munkahelyról a másikra való lépéseiket magyarázzák. Kiegészül mindez azzal, hogy a karrierdöntésekben nem csupán szakmai szempontok kerülnek mérlegelésre, hanem az élet más területeihez kötődô szerepek is befolyásoló tényezók lehetnek. Ezekben megjelenik a magánéletet, vagy az integrált ént, valamint az értékrendet, értékütközések érintố kérdések vizsgálata. A minták alapján látszik, hogy például a nók azok, akik jellemzóen a magánéle szerepeik konfliktusából kiinduló váltásokat fogalmaznak meg, illetve - az önismeret kritikai olvasatához kapcsolódva - például a pszichológiához közeli szakmákban dolgozók beszélnek gyakrabban a különbözó szerepeik inegrapanan úgy tünik, változása bizonyos jellemzók mentén eltéró lehet, vélhetôen a korosztálybeli különbségeket is érdemes vizsgálni.

A karrierértelmezésekre továbbá a narratív elemzésen keresztül is következtetünk, itt most a sikere ség narratíváját emeljük ki. Izgalmas kérdés, hogy a siker definiálása miképp ad képet a karrierértelmezésról. A mintáknál már megfogalmaztuk a siker megalkotásának eltérő értelmezéseit: az elhagyás jelleg karriernarratíváknak fontos eleme a kényszerek átértelmezése aktív szereppé, amely eredményeképp a „fốhôs" jó döntést hoz, míg a keresés jellegú narratívák fớ ívét a „belső út” hangsúlyozása adta, az átlépés jellegû́ valtán egyfajta hez való viszony ellont alanyaink. áśción célok elêresérôl úgy tûnik, már kevésbé illik beszélni, míg az önirányítás és „belső út” pszichológiai siker az, ami kívánatos eleme lett a karrierútnak. Ebben értelemben valóban megfigyelhetó a szakirodalon által jelzett eltolódás a siker materiális jellege felól pszichologiai felé. A siker tartalmának változását magyarázó mélyebb összefüggések feltárása egy olyan további elemzési szempont, amely most nem képezi az elemzés tárgyát, de szorosan kapcsolódik a karrierre kapcsolatos magatartás megértéséhez.

\section{Zárszó}

Tanulmányunkban arra tettünk kísérletet, hogy a karrierváltásról, a karrierrel kapcsolatos magatartásról, karrierfelfogások és -definíciók változásáról a váltás folyamat bemutatásán keresztül adjunk képet. Min ehhez olyan elemzési eljárást választottunk, amel a karrierváltást nem egyszerúsíti csupán objektív tényezókben bekōvetkezó változásokra, sem az egyén jellemzók általánosított kategorizálására. A minták több szempontú, komplex leírása lehetôvé tette, hogy a tartalmi elemek mellett a narratív elemzés nyujtot

\section{VEZETÉSTUDOMÁNY}

kutatói értelmezéseinket, olvasatainkat is bemutassuk. z általunk választott elemzési módszer természetesen számos ponton továbbfejleszthetô, mindazonáltal bízunk benne, hogy nem csupán a hazai karrierváltások megismeréséhez, hanem a karrierrel kapcsolatos magatartás megértéséhez is sikerült hozzájárulnunk.

\section{Lábjegyzet}

A protean szó jelentése: ezerarcú, változó, változatos, mozgalmas. formaváltó karrierként jelenik sokrétú, a magyar szakirodalomban használjuk.

Ezek az ún. boundaryless szervezetek, amely elnevezés Jack Welchtól, származik, s amely a boundaryless karrier fogalmát is ihlette (Arthur, 1994)

Gyereknevelés céljából, vagy korai, önkéntes nyugdíi formájában. mutatjuk.

A kutatást a kvalitatív megközelítéshez tartozó narratív interjúzási és interjúelemzési módszertannal végeztük, amely az egyéni élettöorténetek feldolgozására alapul (Vajda, 2003). Az interjúprotokollban a fönarratívát a következő kérdéssel indítottuk: „Mesélje el az élettörténetét a karrierváltásai szempontjából."

\section{Felhasznált irodalom}

Argyris, C. (1977): Double Loop Learning in Organizations. Harvard Business Review, September-October, p. 115-124. Arthur, M.B. (1994): The boundaryless career: a new perspective for organizational inquiry, Journal of Organizational Behavior, Vol. 15,4, p. 295-306.

Bokor - Fertetics - Hidegh - Váradi Szabó (2009): Karriertéstudomány, XL. évf., 11. szám, p. 11-35.

DeFilippi, R.J. - Arthur, M.B. (1994): The bounderyless career: a competency-based perspective, Journal of Organizational Behavior, Vol. 15, 4, p. 307-324.

Gattiker, U.E., - Larwood, L. (1988). Predictors of managers' career mobility, success,and satisfaction. Human Relations, vol. 41, p. 569-591.

Hall, D.T. (1996): Protean Careers of the 21 st Century, Academy of Management Executive, Vol. 10, No. 4

Hall, D.T. - Mirvis, Ph.H. (1995): The New Career Contract: Developing the Whole Person at Midlife and Beyond, Journal of Vocational Behavior, Vol. 47, p. 269-289.

Hall, D.T. - Moss, J.E. (1998): The New Protean Career Contract: Helping Organizations and Employees Adapt, Organizational Dynamics, Winter, 26(3), pp. 22-37.

Herr, E.L. - Cramer, S.H. - Niles, S.G. (2004): Career Guidance and Counseling Through the Lifespan: Sistemic Approaches (6th Ed.), Allyn \& Bacon, Boston, Maryland

Herzberg, F.I. (1987): 'One more time: How do you motivate employees?, Harvard Business Review, Sep/Oct87, 65, Issue 5, p. 109-120.

Koncz K. (2002): Karriermenedzsment, Aula Kiadó, Bp. 
Lieblich, A. - Tuval-Mashiach, R. - Zilber T. (1998): Narrative Research Reading, Analysis, and Interpretation, Sage Publications

Mirvis, Ph.H. - Hall, D.T. (1994): Psychological success and the boundaryless career, Journal of Ogranization Behavior, Vol. 15, p. 365-380.

Niles, S.G. - Harris 2 Bowlsbey, J. (2002): Career Development Interventions In The 21th Century, Pearsons Education, Inc., New Jersey, New York

Patton, W. - McMahon, M. (2006): Career Development and Systems Theory. Connecting Theory and Practice. (2nd Ed.), Sense Publishers, Australia

Riessman, C.K. (2008): Narrative Methods for the Human Sciences, Sage Publications

Sargent, L.D. - Domberger Sh.R. (2007): Exploring the development of a protean career orientation: values and image violations, Career Development International, Vol. 12, No. 6, p. 545-564.

Sullivan, Sh.E. (1999): The Changing Nature of careers: a Review and Research Agenda, Journal of Management, Vol. 25, No 3, p. 457-484.

Sullivan, Sh.E. - Carden, W.A. - Martin D.F. (1998): Careers in the next millenium: directions for the future research, Human Resource Management Review, Vol 8, Nb 2, p. 165-185.

Toarniczky, A. (2009): Szervezeti szocializáció, Vezetéstudomány, XL. évf., 11. szám, p. 52-59.

Vajda, J. (2003): Az élettörténet szövegének szövete. JelKép, 2003. 1.sz. p. 89-96.

Cikk beérkezett: 2009. 11. hó

Lektori vélemény alapján véglegesítve: 2009. 12. hó

\section{Szerzóinknek}

A Vezetéstudomány a Budapesti Corvinus Egyetem Gazdálkodástudományi Karának havi, referált folyóirata. Alapban a vezetési és gazdálkodási tudományterületekhez kapcsolódó témakörök elméleti és gyakorlati kérdéseit elemző és vizsgáló írások jelennek meg. A szerkesztőség (robert.becsky@ uni-corvinus.hu) elektronikus formában kéri az írásokat. A cikkeket elektronikus levélben (MS Word fájl formátumban) lehet a szerkesztőséghez eljuttatni.

A lap tudományos folyóirat, ezért szövegközi forráshivatkozások és ezek jegyzéke nélküli írásokat nem jelentet meg. A Vezetéstudományban megjelentetni szándékozott kéziratok szerzőitől az alábbi követelmények figyelembevételét kérjük:

- A cikkek szokásos terjedelme a hivatkozásokkal, ábrákkal és táblázatokkal együtt 20-24 oldal, 1,5-es sortávolsággal (12-es betüméret, Times New Roman betûtípus).

- A cikkek első oldalának alján tüntessék fel a szerző foglalkozását, munkahelyét és beosztását, elektronikus levelezési címét, a tanulmány elkészítésével kapcsolatos információkat és az esetleges köszönetnyilvánításokat.

- A kézirathoz csatolandó egy magyar nyelvú és lehetôség szerint egy angol nyelvú rövid összefoglaló (200 szót nem meghaladó terjedelemben), valamint a cikk fó témaköreit megnevezô kulcsszavak jegyzéke.

- Kiemeléshez félkövér és dólt betü használható, aláhúzás nem. Jegyzeteket lehetóleg ne használjanak, amenynyiben azok feltétlenül szükségesek, szövegvégi jegyzetként adják meg.

- A táblázatoknak és ábráknak legyen sorszáma és címe, valamint - átvett forrás esetén - pontos hivatkozása.

- Az ábrákat és a táblázatokat a kézirat végén, külön oldalakon, sorszámmal és címmel ellátva kérjük csatolni, helyüket a szövegben egyértelmúen jelölve (pl. „Kérem az 1. táblázatot kb. itt elhelyezni!").

- A szövegközi bibliográfiai hivatkozásokat zárójelben, a vezetéknév és az évszám feltüntetésével kérjük jelölni: pl. (Veress, 1999); szó szerinti, idézőjeles hivatkozás esetén kiegészítve az oldal(ak) számával (pl. Prahalad - Hamel, 1990: 85.).

- Amennyiben egy hivatkozott szerzőnek több bibliográfiai tétele van ugyanazon évben, ezeket 1999a, 1999b stb. módon kell megkülönböztetni.

- A felhasznált források cikk végén elhelyezett jegyzékét ábécérendben kérjük, a következő formában:

1. példa (könyv): Porter, M.E. (1980): Competitive Strategy; New York: The Free Press

2. példa (folyóiratcikk): Prahalad, C.K. - Hamel, G. (1990): The Core Competence of the Corporation; Harvard Business Review, május-június, 79-91. o.

A formai követelmények fentiekben érvényesített, ún. „Harvard” rendszeréról (más néven „szerzólév” vagy „,név/ dátum" hivatkozási módszerról) részletes tájékoztatást nyújtanak az alábbi WEB-címeken elérhető források.

Havi folyóirat lévén és a megjelenés átfutási idejének csökkentése érdekében a Vezetéstudomány kefelevonatot nem küld, elfogadás előtt azonban a szerzóknek egyeztetés céljából elküldi a cikk szerkesztett változatát.

2009. januártól a Vezetéstudományban publikált cikkek elérhetốek az ISI Eme „www.securities.com" internetcímen található strukturált on-line információs adatbázisban. 2009 júniusától a Vezetéstudományban közölt írások elérhetốek az EBSCO Academic Search Complete adatbázisában a http://web.ebscohost.com/ehost/ search ?vid=20\& hid $=102 \&$ sid $=747 a 764 f-362 f-4683-9255$ 4 54f5ba0df7\%40sessionmgr 112 oldalon is.

Külön kívánságra 2004-ig visszamenóleg az összes korábbi kiadás publikációit elektronikus változatban is elküldjük.

Ha a szerző nem járul hozzá cikkének eseti kérésre, elektronikus úton való továbbadásához, kérjük, előre közölje ezt. 